
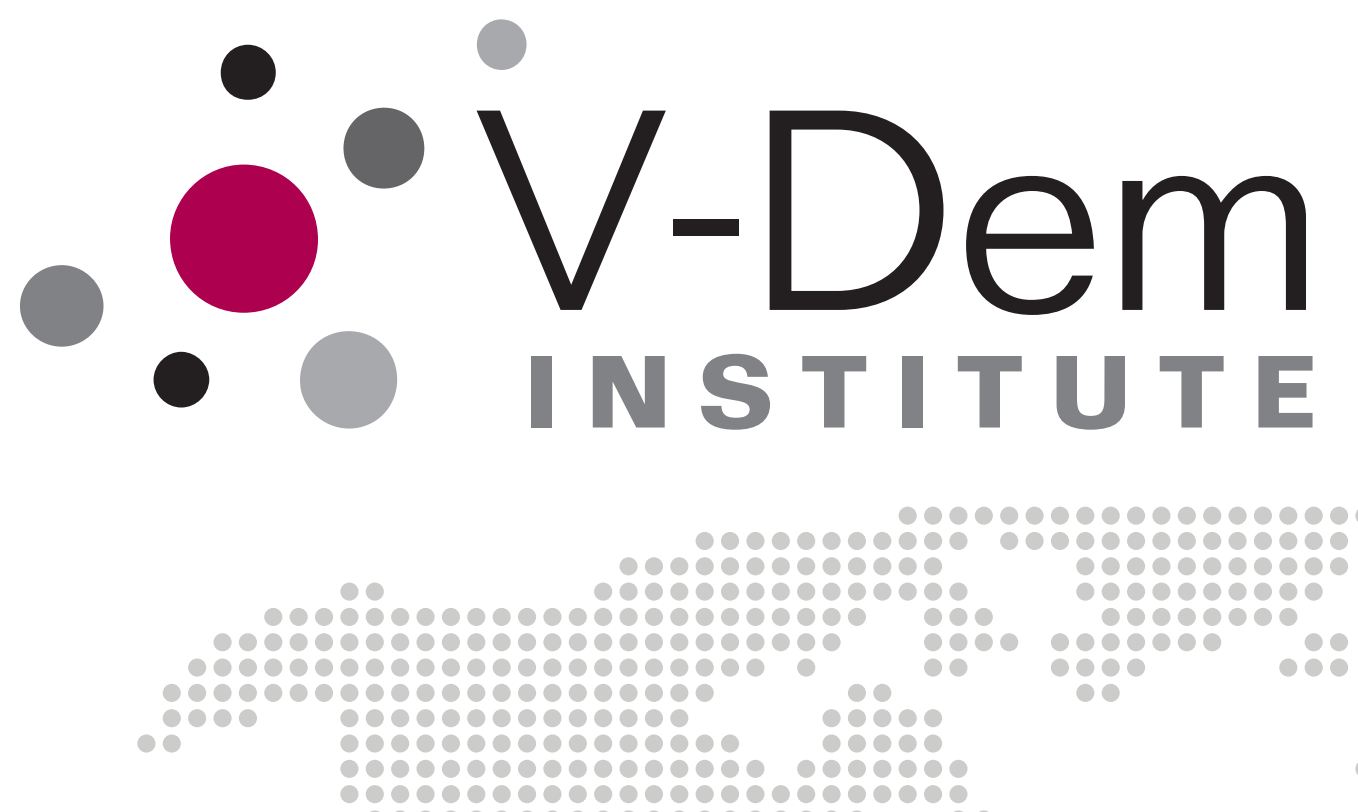

Electoral Volatility and Regime Survival in Competitive Authoritarian Regimes

Wooseok Kim

Michael Bernhard Allen Hicken
00000000

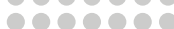

0000000

10000

1000

000

1000

10

100

90
00000

100

090090

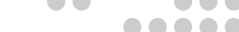

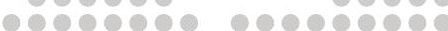
$000000000000000 \mathrm{c}$

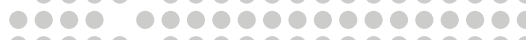

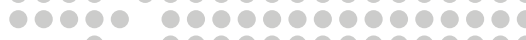
-

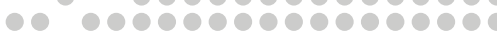

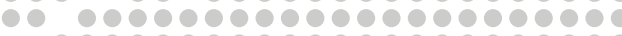
100000000000000000

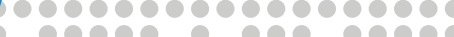

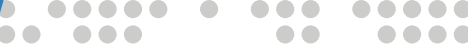

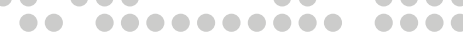

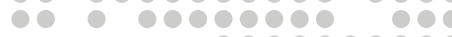

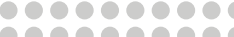
1

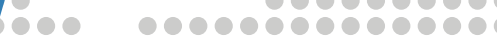

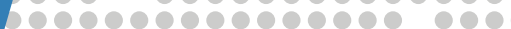

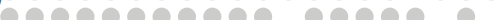
-

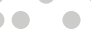

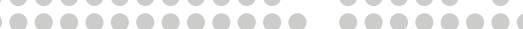

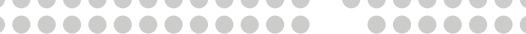
1000000000000000000

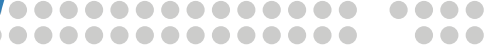

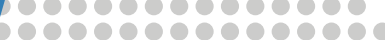
P0090909000009000090 00000000000000000000 000000000000000

о000900009090908

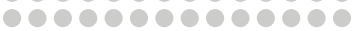

0000000000000

10000000000

0000000000

o

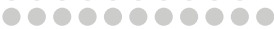

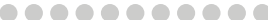
00000000000

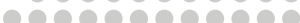

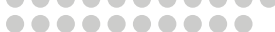
6е890808 000000000 0000000

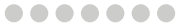

00000

0000

000
10

0
0
0
0

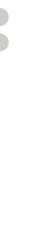
(n) 
Varieties of Democracy (V-Dem) is a unique approach to conceptualization and measurement of democracy. The headquarters - the V-Dem Institute - is based at the University of Gothenburg with 20 staff. The project includes a worldwide team with 5 Principal Investigators, 22 Project Managers, 33 Regional Managers, 134 Country Coordinators, Research Assistants, and 3,500 Country Experts. The V-Dem project is one of the largest ever social science research-oriented data collection programs.

Please address comments and/or queries to:

\author{
V-Dem Institute \\ Department of Political Science \\ University of Gothenburg \\ Sprängkullsgatan 19, Box 711 \\ 40530 Gothenburg \\ Sweden \\ E-mail: contact@v-dem.net
}

V-Dem Working Papers are available in electronic format at https://www.v-dem.net

Copyright (C2022 by authors. All rights reserved. 


\title{
Electoral Volatility and Regime Survival in \\ Competitive Authoritarian Regimes
}

\author{
Wooseok Kim \\ University of Michigan \\ Michael Bernhard \\ University of Florida \\ Allen Hicken \\ University of Michigan
}




\begin{abstract}
Party system institutionalization is regarded as a critical underpinning of democracies, but its role in non-democratic systems has been understudied. In this paper, we evaluate whether the concept has meaningful and perhaps unique implications for the durability of competitive authoritarian regimes. We argue that electoral volatility-the most common measure of party system institutionalization in democracies - conveys useful information in competitive authoritarian contexts by signaling the ability of the ruling party to manage the opposition, but note that it needs to be refined to be applicable to such contexts. To this end, we construct an original data set that disaggregates electoral volatility into ruling party seat change and opposition party seat volatility, and further divide opposition party volatility into Type-A and Type-B volatility. We find robust results that democratization becomes more likely when decreases in the ruling party's seat share are accompanied by opposition party Type-B volatility. This paper demonstrates that the concept of party system institutionalization can be useful for making sense of regime dynamics even in non-democratic contexts.
\end{abstract}




\section{Introduction}

Since Mainwaring and Scully's (1995) formative work on party systems in Latin America, the concept of party system institutionalization-or the stability and predictability of patterns of interparty competition — has been widely applied to explain variations in the performance and consolidation of democratic institutions. Party system institutionalization has come to be regarded as a critical underpinning of democracy as it facilitates representation and governance, with defective patterns linked to ineffective democratic institutions and even democratic backsliding.

While the study of party systems has been a staple in the comparative analysis of democracies, the role that party systems play in authoritarian contexts has largely gone unexplored. This is not without reason, as interparty competition was nonexistent or irrelevant in many traditional authoritarian regimes. However, the rise of new forms of competitive authoritarianism engendered party systems in which a dominant ruling party "competes" against opposition parties, albeit while enjoying significant structural and resource advantages. Elections in these regimes are fundamentally distinct from those typically observed in democracies given that they occur on an uneven playing field and are not primarily focused on representation or governance, but provide institutional channels through which incumbents can extend and legitimize their rule. Thus, the patterns of interparty competition observed in these competitive authoritarian regimes carry greater significance for regime stability since they form the foundation of the regime. A democratic regime can remain robust even when its party system experiences significant turnover-such turnover could even be a reflection of properly functioning democratic institutions-but a competitive authoritarian regime is likely to be much more fragile in the aftermath of substantial party system change. As such, the study of party system institutionalization in competitive authoritarian regimes should not only be valuable, but also necessary for understanding the development and fate of such regimes.

Our main argument is that the durability of a competitive authoritarian regime is contingent on the institutionalization of the party system, which in turn is a function of the ability of the ruling party to pacify opposition challenges in the electoral arena and consolidate its status as the dominant actor within the party system. An extensive body of research highlights the importance of elections for strengthening authoritarian rule (e.g., Levitsky and Way 2010), but also demonstrates that such elections still carry varying degrees of uncertainty and do trigger authoritarian breakdown (e.g., Bernhard, Edgell, and Lindberg 2020). We suggest that the stability and predictability of interparty competition reflects the extent to which ruling parties manage to resolve such electoral uncertainties. Our discussion of this relationship generalizes some of the implications of Magaloni's (2010) formal model of electoral fraud in autocracies. Specifically, we 
explore how the establishment of an "autocratic collusive equilibrium" through cooptation and repression can curb the ability and incentives of the opposition to disrupt the status quo, which enables ruling parties to "reap the fruits of electoral legitimacy without running the risks of democratic uncertainty" (Schedler 2002, 37) and prolong their stay in power.

To test our argument, we operationalize party system institutionalization with Pedersen's index of electoral volatility, which is the standard measure of the concept in comparative studies of democracy. However, in authoritarian settings, this system-level electoral volatility measure conflates ruling party and opposition party electoral dynamics, and thus is less useful for our purposes since each type of volatility can have disparate consequences for authoritarian incumbents. As such, we disaggregate the system-level measure into ruling party seat change and opposition party seat volatility, and also divide the latter into Type-A volatility (caused by the entry and exit of opposition parties) and Type-B volatility (caused by shifts in seat shares between existing opposition parties).

Our newly constructed dataset of electoral volatility covers 111 competitive authoritarian regimes across 79 countries from 1945-2018, and we use the dataset to conduct the first large-N cross-national study of party system institutionalization's implications in non-democratic contexts. More specifically, we assess the extent to which different forms of electoral volatility foreshadow the demise of competitive authoritarian regimes, and whether such demise is brought about by authoritarian replacement or democratic transition. Our principal finding is that an erosion of the ruling party's electoral performance combined with a disruption of the competitive equilibrium among existing opposition parties (i.e., a rise in opposition party Type-B volatility) is a robust predictor of competitive authoritarian breakdown in the form of democratization. This result runs counter to expectations about electoral volatility and regime stability in democracies, which suggest that Type-A rather than Type-B volatility is particularly inimical to the consolidation of democracy. In sum, we demonstrate that party system institutionalization can be a useful concept for understanding the performance and survival of non-democratic regimes.

The paper is organized as follows: in the next section, we review the existing literature on party system institutionalization in democracies before discussing the applicability of the concept to authoritarian contexts; in section three, we develop hypotheses that link different types of electoral volatility with the survival and collapse of competitive authoritarian regimes; in section four, we discuss our data, empirical strategy, and results; in section five, we provide concluding remarks. 


\section{Party System Institutionalization across Regimes}

\section{Party System Institutionalization in Democracies}

Institutionalized party systems are those in which "a stable set of parties interact regularly in stable ways" (Mainwaring 1999); a consistent set of parties compete against one another, form alliances, and enter government. As a result of these regular interactions, political actors come to acquire credible information about the parties and their preferences, and develop expectations that existing patterns of interparty competition will persist.

The notion of party system institutionalization grows out of classic work on the origins and viability of democracy. In their foundational study, Lipset and Rokkan (1967) argue that a series of political cleavages intrinsic to the emergence of modernity in Western Europe-center versus periphery, state versus church, owner versus worker, and rural versus urban-became frozen in the late nineteenth and early twentieth centuries and continued to structure party competition for decades after. The creation of durable and regular structures of interparty competition was regarded as a characteristic of successful democratization, ${ }^{1}$ and subsequent studies in Western Europe created a set of expectations about the development of institutionalized party systems in democracies. For example, Bartolini and Mair (1990), using data from 13 longstanding West European democracies that span a century, show that party systems became destabilized after the onset of competitive elections before settling into regular patterns of interparty competition (also see Rose and Urwin 1979). Such works were seen as confirming Lipset and Rokkan's (1967) theory of durable cleavages. ${ }^{2}$

The historical patterns observed in Europe do not seem to hold for the rest of the world, however. Instead of early elections functioning as a "great electoral lottery" (Innes 2002) that settle which parties would become mainstays of an institutionalized system, the weeding out period has proved to be of longer duration or shown no signs of ever abating in many newer democracies (Bielasiak 2005; Mainwaring and Zoco 2007). The evidence is extensive and covers many regions, including Latin America (Cohen, Kobilanski, and Zechmeister 2018; Madrid 2005; Roberts 2014; Roberts and Wibbels 1999), Eastern Europe (Bernhard and Karakoc 2011; Bielasiak 2002; Haughton and Deegan-Krause 2020; Kitschelt et al. 1999; Tavits 2005), Asia (Hicken and Kuhonta 2011, 2014; Stockton 2001; Ufen 2013; Wilkinson 2015), and Africa (Ferree 2010; Kuenzi and Lambright 2005; Mozaffar and Scarritt 2005; Riedl 2014; Weghorst and Bernhard 2014).

\footnotetext{
${ }^{1}$ However, these cleavages have thawed over time in the face of new divisions over issues such as post-materialist values (Inglehart 1977; Kitschelt 1989) and globalization (Hooghe and Marks 2018; Kriesi et al. 2008).

2 See Casal Bértoa and Enyedi (2021) for a more recent analysis of party system institutionalization in Europe.
} 
These developments are troubling because under-institutionalized party systems hinder representation and governance, and thus impair the smooth functioning of democracy. Parties channel and give expression to interests through the way they frame issues and pursue policies, and weakly institutionalized party systems shorten time horizons and reduce the incentives and abilities of parties to coordinate and implement policies that reflect voter preferences (Mainwaring and Scully 1995; Sartori 1976; Schleiter and Voznaya 2016). Parties are also essential for effective governance, and erratic or short-lived governing coalitions can debilitate governments, making rule unpredictable and/or ineffective (Mainwaring and Scully 1995; Lupu and Stokes 2010; Stokes 2001; Helmke 2017; Hicken 2018). Moreover, parties play a central role in opposition; they are one of the key actors who hold governments accountable by imposing audience costs and exercising horizontal constraints for both poorly performing governments and those who try to overreach in their exercise of power (Bernhard et al. 2020).

Sartori (1976) was among the first to point out that "formless," i.e., uninstitutionalized, party systems are more likely to succumb to one-party dictatorships or overthrow by coup d'état. Democracies with weakly institutionalized party systems have also been shown to be more prone to breakdown (Bernhard et al. 2020), and the collapse of party systems has been identified a central mechanism in some cases of democratic backsliding (Seawright 2012; Morgan 2011; Helmke 2010, 2017). Ultimately, the failure to develop institutionalized party systems in democracies can lead to unstructured polities in which policy is incoherent, government disorganized, governance ineffective, and accountability weak, thus leading to endemic instability or democratic failure.

\section{Party System Institutionalization in Authoritarian Regimes}

Contrary to democracies, there has been very little call to study party system institutionalization in authoritarian regimes given that most conventional authoritarian regimes were either no-party or one-party regimes. No-party authoritarian regimes, by definition, are devoid of meaningful parties or interparty competition. In one-party authoritarian regimes, which are one of the most important subtypes of historical authoritarianism, the ruling party is the preeminent political actor and any minor parties that are permitted to exist are often fully licensed satellites subservient to the ruling party. Compared to other forms of conventional authoritarianism, these one-party regimes have been able to project expansive infrastructural power (Mann 1984) that reach broadly and deeply into society (Slater 2008), and they represent the most highly institutionalized and stable form of authoritarianism for most of the twentieth century, as demonstrated by their long and durable tenures in power (Geddes, Wright and Frantz 2018; Smith 2007). In these regimes, the ruling parties may call noncompetitive elections whose plebiscitary nature make them exercises in the 
public signaling of loyalty to the regime (Havel 2018; Zaslavsky and Brym 1978), where the official slate of candidates consistently secures overwhelming majorities. The essence of no-party and oneparty regimes is a monopoly of political organization by the authoritarian incumbents (Przeworski 1991) and an absence or a highly constrained degree of party subsystem autonomy (Sartori 1976). The study of party systems institutionalization in such contexts is effectively meaningless, as one cannot reasonably speak of a system that only has one (or no) constituent units.

\section{Party System Institutionalization in Competitive Authoritarian Regimes}

Over the last four decades, the number of authoritarian regimes that do not allow elections, prohibit opposition parties, or where electoral results bear no relationship to votes cast, has become increasingly small. By the mid- to late-1990s, the number of electoral authoritarian regimes surpassed that of conventional authoritarian regimes (Lührmann, Tannenberg, and Lindberg 2018, 67, 76-77), and the discipline has had to wrestle with the rise of authoritarian regimes that relax the monopoly of political organization and permit some degree of electoral competition and party subsystem autonomy.

In competitive authoritarian regimes, opposition parties are allowed to compete against the ruling party and electoral results are generally dependent on the votes cast. However, such interparty competition is constrained by the structural and resource advantages granted to the incumbent holders of state power and the range of manipulative strategies available to them, which can - if wielded effectively_shield incumbents from electoral punishment and diminish the probability that they cede power (Levitsky and Way 2010). A large number of authors argue that elections hold the key to maintaining credible commitments within the ruling authoritarian coalition by providing a mechanism for distributing rents (Boix and Svolik 2013; Magaloni 2008; Svolik 2012; Wright and Escribà-Folch 2012), effectively containing popular challenges to authoritarian rule by coopting or disrupting counter-elites who could lead popular challenges to incumbent authority (Arriola, Devaro, and Meng 2021; Gandhi and Przeworski 2007; Lust-Okar 2009), granting concessions to important social constituencies to garner popular support (Greene 2010), and regularizing popular legitimation via electoral competition (Schedler 2002). Nonetheless, elections can be a double-edged sword for ruling parties (Bernhard, Edgell, and Lindberg 2020) as they can amplify the voices of disgruntled actors against ruling incumbents, and facilitate the solution of collective action problems that complicate effective opposition coordination (Knutsen, Nygård, and Wig 2017; Tucker 2007). Thus, elections in competitive authoritarian regimes are not devoid of uncertainty. 
We argue that the durability of competitive authoritarian regimes is a function of the ability of ruling parties to minimize such uncertainty by taming the opposition in the electoral arena, which should promote the institutionalization of the party system. Elections provide ruling parties with information about the degree and sources of elite and mass support, and ruling parties can exploit such information to identify and appease key opposition actors via access to appointments and spoils while punishing defectors and those who continually resist the regime. Such strategies create perverse incentives for the coopted opposition to participate in elections without truly challenging the ruling party to maintain good standing and the flow of benefits, and this acquiescence through participation legitimizes the ruling party, which simultaneously divides and demotivates anti-regime supporters and thereby diminishes threats to the regime. As ruling parties establish this "autocratic collusive equilibrium" (Magaloni 2010) by successfully managing elites, opposition parties, and larger groups within society through elections, patterns of interparty competition should become more stable and predictable, and expectations that the party system status quo-which revolves around and is dominated by the ruling party-will persist into the future should become stronger. Consequently, and contrary to democracies in which institutionalized party systems typically manifest in familiar sets of parties alternating in power, institutionalized party systems in competitive authoritarian regimes contribute to the entrenchment of the ruling party. When incumbents fail to effectively contain and control the opposition through elections and develop institutionalized patterns of interparty competition, they face greater prospects of electoral loss or the necessity of using repression to hold on to power. This has negative ramifications for the incumbent's rule, including undermining the claim that their hold on power is legitimized by a popular mandate and exposing their vulnerabilities, which subsequently undermines the durability of the regime.

Thus, our expectation is that party system institutionalization should be an important correlate of the survival and breakdown of competitive authoritarian regimes. In the next section, we propose a novel measure that unpacks the different insights that electoral volatility can provide for assessing the stability and predictability of patterns of interparty competition in competitive authoritarian regimes. 


\section{Electoral Volatility across Regimes}

\section{Electoral Volatility in Democracies}

Party system institutionalization is commonly measured with electoral volatility (Pedersen 1979), which aggregates the movement of seats (or votes) ${ }^{3}$ from party to party across elections: ${ }^{4}$

$$
E V_{t}=\frac{\sum_{i=1}^{N}\left|p_{i, t}-p_{i, t-1}\right|}{2}
$$

where $p_{i, t}$ is the seat share obtained by party $i$ in election $t$. This system-level measure of volatility ranges from 0 to 100 , with a value of 0 indicating no change in the composition of the legislature across two consecutive elections, and a value of 100 indicating that the composition of the legislature in election $\mathrm{t}$ is completely novel relative to election $t-1$.

Generally speaking, consistently high levels of volatility are associated with underinstitutionalized party systems and indicate the inability of the existing parties to develop stable and predictable interparty interactions. ${ }^{5}$ More recent work by Powell and Tucker (2014) differentiates between Type-A and Type-B volatility, where Type-A volatility captures the entry and exit of parties from the system, and Type-B reflects the reallocation of seats between existing parties. Type-A volatility is thought to be potentially dangerous and destabilizing for democracies, whereas Type-B is regarded as a reflection of the normal operation of vertical accountability wherein voters redistribute their support based on their satisfaction with the incumbent.

\section{Electoral Volatility in Authoritarian Regimes}

Does electoral volatility convey any useful information in authoritarian contexts? Is it an indicator with any validity and utility where party competition is less than fully competitive? To begin, there are three settings in which an application of electoral volatility would be nonsensical, superfluous, or misleading. In the first category are regimes in which there are no direct national elections or where political parties are not allowed (e.g., China). The second category includes regimes that hold elections in which only ruling party is allowed to compete as a party (e.g., Vietnam). In the final category would be regimes in which electoral results have little relationship to underlying voter preferences as expressed through the ballot (e.g., cases with massive electoral fraud or those in which officials are not elected through popular elections). Where these conditions hold, electoral volatility is not useful for making sense of underlying political dynamics between the ruling party and opposition parties.

\footnotetext{
${ }^{3}$ Since legislative outcomes generally reflect electoral outcomes and legislatures are important arenas for opposition coordination and contestation, we focus on changes in seat shares.

${ }^{4}$ See Casal Bértoa and Enyedi (2021) for a novel, though data-intensive, alternative to electoral volatility.

${ }^{5}$ Singular episodes of high volatility are more indicative of party system realignments.
} 


\section{Electoral Volatility in Competitive Authoritarian Regimes}

On the other hand, we expect electoral volatility to provide valuable information in competitive authoritarian contexts. Some could contest this point by arguing that electoral results in these regimes are endogenous to incumbent preferences, and thus convey little else apart from the incumbent's strategic decisions over how much competition to allow, who will be allowed to vote, and what dirty tricks to employ to ensure the desired result. To accept this view, however, is to reject the assumptions of competitive authoritarianism as a concept and ignore the compelling evidence that the chance of incumbent loss is non-negligible. Despite their best laid plans, incumbents of competitive authoritarian regimes can be surprised by election results and do, sometimes, lose elections. Research has shown that these regimes can be both vulnerable and relatively fragile (Bernhard, Edgell and Lindberg 2020; Bunce and Wolchik 2011; Knutsen, Nygård, and Wig 2017), and almost two-thirds of the competitive authoritarian regimes we sample in this paper eventually come to an end. Thus, unless one is willing to assume that incumbents are more interested in losing than winning, then elections and subsequent patterns of interparty competition should offer meaningful insight into the strength and durability of competitive authoritarian regimes.

But what specific information can electoral volatility provide about competitive authoritarian regimes? While system-level volatility measures are applicable to democracies given that patterns of interparty competition do not usually revolve around a single party, this is clearly not the case in competitive authoritarian regimes where the significance of the ruling party's electoral performance eclipses that of the other parties in the system, and the fate of the regime is directly tied to the fate of the ruling party. Thus, we suggest that the measure needs to be explored in ways that go beyond its application in democracies to be suitable for making sense of electoral dynamics in competitive authoritarian regimes.

More specifically, we treat changes in the seat shares held by the ruling party and opposition parties as distinct components of volatility. We first disaggregate electoral volatility to capture changes in the ruling party's seat share across two elections. Whereas conventional calculations of electoral volatility use absolute changes in seat shares, we expect the direction of change in the ruling party's seat share to be consequential given the ruling party's position within the party system, e.g., a 20 percent decrease in the ruling party's seat share has very different implications compared to a 20 percent increase. Thus, we allow the measure to be positive or negative. We then calculate opposition party volatility following conventional calculations of Pedersen's index, but only using seat shares won by the opposition parties (i.e., excluding the ruling party's seat share), and further divide this measure into Type-A (seat share changes resulting from 
the entry and exit of opposition parties) and Type-B volatility (changes in the distribution of seat shares between existing opposition parties). Figure 1 below demonstrates how we disaggregate the system-level measure of electoral volatility into its subcomponents.

Figure 1. Electoral Volatility in Competitive Authoritarian Regimes Disaggregated

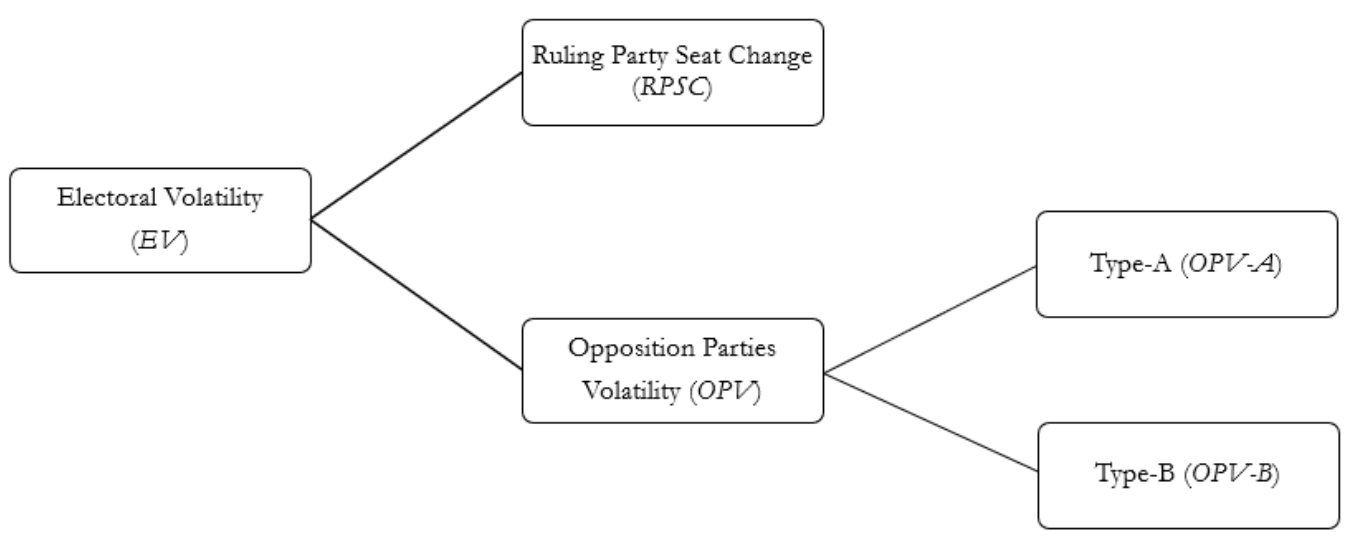

\section{Hypotheses}

In this section, we present hypotheses that link these different types of volatility to the survival and breakdown of competitive authoritarian regimes. Central to our argument is the idea that the capability of the ruling party to manage the party system through elections is a key to the durability of these regimes.

We begin with system-level electoral volatility. Contrary to democracies, we suggest that high system-level electoral volatility is unlikely to be a strong predictor of the durability of competitive authoritarian regimes since the measure conflates ruling party and opposition party electoral dynamics:

H1: System-level electoral volatility should not be associated with regime breakdown.

Turning to the disaggregated measures of electoral volatility, we expect decreases (increases) in the ruling party's seat share to indicate a weakening (strengthening) of the ruling party:

H2: Negative (positive) ruling party seat change is associated with a higher (lower) risk of regime breakdown. 
Opposition party volatility should be low when the opposition is content with the collusive equilibrium established by the ruling party and has fewer incentives to launch genuine challenges against the status quo. Thus, low opposition volatility can signal that the opposition has been tamed, contained, or sufficiently handicapped. On a popular level, it signals the satisfaction, resignation, or apathy of voters. High volatility, on the other hand, could be the result of defection or splits at the level of party elites that aim to alter the status quo, or the result of voters expressing their discontent with the existing arrangement of parties. And while we do not argue that such volatility itself causes regime breakdown, it does reflect the deterioration of the ruling party's ability to manage the opposition in the electoral arena, and could well portend the fall of the regime.

H3: Higher opposition party volatility is associated with a higher risk of regime breakdown.

We also disaggregate opposition party volatility into Type-A and Type-B volatility. In democracies, Type-A volatility is regarded as being inimical to democratic consolidation (except in the one or two elections following a democratic founding or in the case of a successful party system realignment), while moderate Type-B volatility is generally regarded as a manifestation of a healthy and competitive democracy. Such patterns are likely to be reversed in competitive authoritarian regimes. We hypothesize that Type-A volatility will not be associated with regime breakdown, though this is not because we regard the entry and exit of opposition parties as inconsequential. We acknowledge that some cases of opposition party entry and exit may represent the rise of new significant challengers or the failure of the ruling party to satisfy key opposition parties, which could threaten the regime's dominance. Conversely, such electoral patterns could be a result of the ruling party's strategic attempts to remake the collusive bargain due to a perceived need to integrate new partners, or the removal of non-compliant and/or weakened opposition partners. Since Type-A volatility conflates such patterns and does not allow us to distinguish between these two processes, it is likely to have ambiguous associations with regime durability. ${ }^{6}$

In contrast, Type-B volatility should be a robust predictor of regime fortunes. Opposition parties that possess the infrastructure, resources, and support to compete and

\footnotetext{
${ }^{6}$ Volatility measures in general are not designed to capture such dynamics because they focus on changes in seat shares and not the identity/characteristics of the parties.
} 
win seats in consecutive elections despite facing electoral disadvantages are more likely to be to be key actors. When these opposition parties and their supporters have been successfully integrated into the collusive equilibrium and shift their attention from contesting the status quo to maintaining it, we should expect their seat shares to be generally stable over time (i.e., low opposition party Type-B volatility), which should be associated with regime stability. On the other hand, high volatility in their seat shares may reflect the inability of the ruling to successfully control key opposition actors and resolve electoral uncertainty, and thus should be linked to a greater likelihood of regime breakdown.

H4a: Opposition party Type-A volatility should not be associated with regime breakdown.

H4b: Opposition party Type-B volatility should be positively associated with a higher risk of regime breakdown.

Lastly, we also consider the interaction between ruling party seat change and opposition party volatility. When a ruling party improves on its past levels of electoral performance, opposition party volatility is in part a consequence of the ruling party exerting control at the expense of the opposition. On the other hand, a ruling party that experiences poor electoral performance may find it more difficult to re-establish a collusive agreement that satisfies an altered and potentially empowered set of opposition bargaining partners. Thus, and based on our preceding discussion, we hypothesize that opposition party Type-B volatility will be associated with a higher risk of regime breakdown only when the ruling party concurrently loses seats, but to be largely inconsequential when the ruling party gains seats. Since we expect opposition party TypeA volatility to have a weak association with regime breakdown, we do not expect its interaction with ruling party seat change to add any meaningful distinction.

H5: Opposition party Type-B volatility should share stronger associations with regime breakdown when ruling party seat change is negative.

In our tests of the hypotheses, we assess whether these various components of electoral volatility are associated with regime breakdown generally, and also with breakdown in the form of authoritarian replacement and democratic transition. Since 
electoral volatility reflects both elite and mass support for the collusive equilibrium, we suggest that it will not be a strong correlate of authoritarian replacement, which is a function of the ability of the ruling party to organize and discipline elite actors (Svolik 2012). To better predict authoritarian replacement, we may well need detailed data on the state of affairs within the incumbent camp and elite-to-elite relations generally, but such data are much harder to come by. As such, we expect transitions from competitive authoritarianism to democracy, which involves both elites and the masses, to drive the results for authoritarian breakdown in our tests.

H6: The disaggregated measures of electoral volatility should share stronger associations with democratic transition relative to authoritarian replacement.

\section{Empirical Analysis}

\section{Competitive Authoritarian Regimes}

We first use the Varieties of Democracy (V-Dem) Regimes of the World variable (Coppedge et al. 2020) to identify electoral autocracies, but incorporate more stringent criteria to construct our sample since not all electoral autocracies are competitive authoritarian. We begin by limiting our sample to regimes that hold minimally competitive multiparty elections with basic de jure provisions of suffrage. ${ }^{7}$ We then drop monarchies, as classified by Geddes et al. (2014). Lastly, we further constrain our sample to regimes in which the ruling party won a minimum of two consecutive elections that meet our baseline criteria since electoral volatility cannot be calculated with one time point. We end up with a final sample that contains 111 ruling party regimes ${ }^{8}$ and 372 elections across 79 post-WWII countries for a total of 940 country-year observations. This makes up less than 30 percent of observations that are classified as electoral autocracies in the V-Dem data set.

\footnotetext{
${ }^{7}$ For minimally competitive elections, we use V-Dem's v2elmulpar_ord variable to identify elections in which "at least one real opposition party is allowed to contest but competition is highly constrained-legally or informally," and further drop elections in which the ruling party won all the seats while obtaining more than 90 percent of the vote. We also use V-Dem's $v 2 x_{-}$suffr variable to drop elections in which less than 25 percent of adult citizens have the legal right to vote to exclude cases such as apartheid-era South Africa from the sample.

${ }^{8}$ We code the party affiliated with the head of state as the ruling party for cases in which the ruling party is unclear. We code a regime as ending but not undergoing transition if it does not hold an election over the next decade or holds an election that does not meet our baseline criteria. As such, a ruling party can preside over more than one regime.
} 


\section{Dependent Variable}

We use two dependent variables and models in our analysis. First, we estimate the conditional probability of regime survival and breakdown using a logistic regression model. Second, following Geddes et al. (2014), we differentiate between two types of regime breakdown by applying a trinary categorical coding scheme that indicates the survival of the ruling party regime, the displacement of the incumbent by another authoritarian regime, or democratic transition. We regard each pair of outcomes as competing failure events and utilize a multinomial logistic regression model to explore whether different types of electoral volatility are associated with particular types of regime breakdown. We match the dependent variables with values of the independent variables from the preceding year. ${ }^{9}$ Around two-thirds of the competitive authoritarian regimes in our sample come to an end; there are 50 instances of authoritarian replacement and 24 instances of democratic transition. ${ }^{10}$

\section{Independent Variables}

We first calculate Pedersen's (1979) index of electoral volatility (EV) using seat share data from general lower house legislative elections. ${ }^{11}$ However, since we expect different types of electoral volatility to have distinct implications for ruling party survival, we further disaggregate the measure. We calculate ruling party seat change (RPSC), which is simply the change in the ruling party seat share across two consecutive elections and can be positive or negative. Opposition party volatility (OPV) is calculated using the Pedersen index excluding ruling party seat shares, and we also break down opposition party volatility into Type-A and Type-B, where opposition party Type-A volatility $(O P V-A)$ reflects changes in the distribution of seat shares caused by the entry and exit of opposition parties, and opposition party Type-B volatility $(O P V-B)$ represents shifts in the distribution of seats between existing opposition parties.

\footnotetext{
9 The dependent variables are matched with values of the independent variable in the same transition year for Bolivia 1964 and Republic of Vietnam 1963 since the ruling parties were removed from power after winning an election in those years. Our results are not sensitive to this coding decision.

10 The remainder of the regimes are right-censored as they were still in power as of 2018 or transitioned to a closed autocracy. We code regimes that intermittently shift between being classified as an electoral autocracy and democracy as undergoing democratic transition if it classified as a democracy in at least 3 of the 5 subsequent years after the regime is first classified as an electoral democracy.

11 Parties with seat shares less than 2 percent or those categorized as "Other" parties in election data are treated as "new" parties in each election. For mergers and coalitions, we compare party seat shares where possible. Parties that undergo dissolution are treated as "exiting" the party system, and any successor parties as "new" parties that enter the party system. If a party experiences a split but the original party continues to contest and win elections, the original party is treated as a continuation of the old party while the faction that broke off from the original party is treated as a "new" party. Parties that simply change their name without undergoing any significant organizational change are coded as being the same party.
} 
Figure 2 plots the different types of electoral volatility. As in democracies, degrees of electoral volatility vary widely in competitive authoritarian regimes. Changes in the ruling party's seat shares are centered around 0 , which indicates that ruling party seat share usually remains steady across elections, as we would expect. Changes in opposition party volatility are generally of higher magnitude, and tend to be driven by opposition party Type-A volatility rather than Type-B volatility. This pattern is unsurprising since opposition parties face significant electoral disadvantages and costs in competitive authoritarian regimes, which can undermine their ability to consistently win seats across elections. Moreover, the lack of uniform trends in electoral dynamics ${ }^{12}$ across the different measures demonstrates that there is some uncertainty about how patterns of interparty competition might unfold in competitive authoritarian regimes.

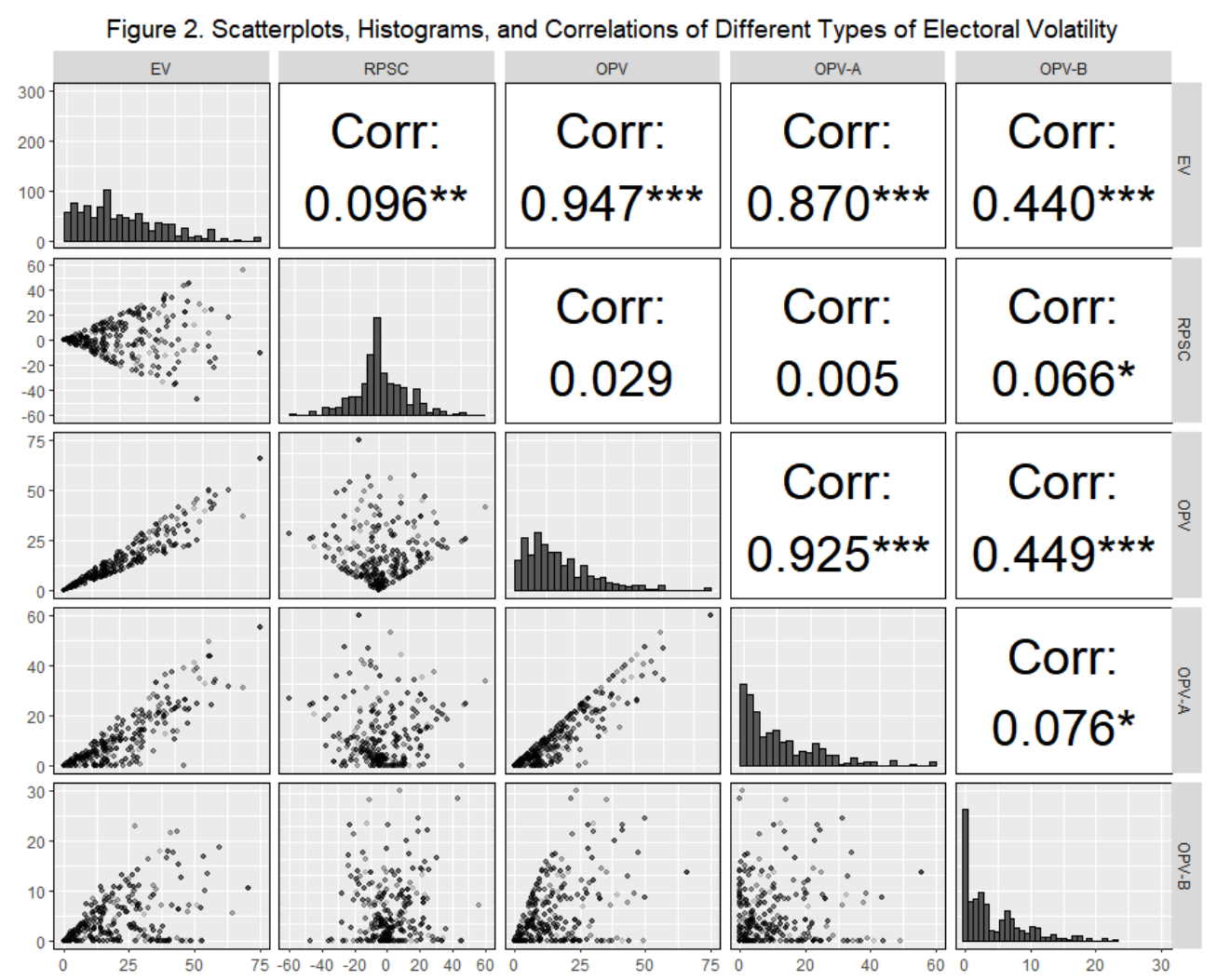

\section{Control Variables}

We also control for other factors that may influence the durability of competitive authoritarian regimes. Ruling parties may become more experienced and better able to

\footnotetext{
12 Ruling party seat change should be accompanied by—at minimum—equivalent levels of opposition party volatility, but the reverse does not hold; the seat share of ruling parties can remain steady even when the distribution of seats between opposition parties undergoes significant transformation.
} 
prolong their rule the longer they are in power. The Regime Age variable counts the number of years that have passed since the regime held its first minimally competitive multiparty election. In addition, elections provide an institutionalized means for opposition parties to challenge the ruling party, and thus we control for Years Since Election, which counts the number of years that have passed since the last competitive multiparty election held by the ruling party. When opportunities to contest the ruling party through electoral institutions become too infrequent, the opposition may be moved to seek extrainstitutional methods of challenging the regime. We also include the effective number of parties $(E N P)$ in our model since, ceteris paribus, the ruling party may find it easier to maintain its position as the dominant party when the party system is more fragmented. We use the natural log of ENP due to the variable's right skew.

Economic development and growth have been frequently linked to regime stability and are measured using the natural log of per capita GDP (GDP per capita) and per capita GDP growth rates (GDP Growth), which are sourced from the Maddison Project (Bolt et al. 2020). Since state capacity dictates the ability of regimes to maintain control of the state apparatus, we include V-Dem's estimate of the percentage of a state's territory over which the state has effective control (Territory Control).

Extensive ethnic fractionalization can foster conflict (Easterly and Levine 1997; Horowitz 1993) that can threaten the stability of regimes, and so we calculate ethnic fractionalization scores $(E F)$ using ethnic data from the Composition of Religious and Ethnic Groups (CREG) data set (Nardulli et al. 2012). While the CREG data set is only available up to 2013, ethnic fractionalization scores change very slowly over time, and thus we use linear prediction based on all past scores to calculate scores for post-2013 years. For the handful of countries that are not covered in the CREG data set, we substitute ethnic fractionalization scores calculated by Alesina et al. (2003). Nonetheless, we show that our results are robust to using observations from the original CREG data set, i.e., without linear prediction and substitution.

We also include a standardized score that reflects the proportion of the losing parties that accept the results of the national election within three months (Election Accepted), which is sourced from the V-Dem data set. Regardless of whether fraud was committed, the decision of opposition parties to contest election outcomes signals their dissatisfaction with the electoral arena or the status quo, which reflects a weakening of the ruling party's control. Furthermore, the presence of an active civil society through which citizens can collectively voice their demands should increase impetus towards 
democratization (Bunce and Wolchik 2011; Kaya and Bernhard 2013; Newton 2001), and so we also include a five-year moving average of V-Dem's Civil Society Participation Index (Civil Society). Lastly, we include the mean regional V-Dem electoral democracy score (Regional Polyarchy) to control for neighborhood democratization effects, and a postCold War (Post-Cold War) dummy variable since electoral authoritarian regimes became much more commonplace during this period. The summary statistics for all variables used in our main models are presented below in Table 1.

Table 1. Summary Statistics

\begin{tabular}{cccccc}
\hline Variable & N & Mean & SD & Min & Max \\
\hline Transition (Binary) & 940 & 0.0787 & 0.2694 & 0 & 1 \\
Transition (Trinary) & 940 & 0.1043 & 0.3803 & 0 & 2 \\
EV & 940 & 19.6822 & 14.727 & 0 & 70.8 \\
RPSC & 940 & 1.7259 & 14.4733 & -46.6667 & 55.8 \\
OPV & 940 & 14.449 & 12.0644 & 0 & 65.9 \\
OPV-A & 940 & 10.3119 & 10.7789 & 0 & 55.5 \\
OPV-B & 940 & 4.1371 & 4.6303 & 0 & 22.95 \\
Regime Age & 940 & 14.483 & 10.477 & 1 & 59 \\
Years Since Election & 940 & 1.6713 & 1.4723 & 0 & 8 \\
ENP (ln) & 940 & 0.5986 & 0.4064 & 1 & 2.0148 \\
GDP per Capita (ln) & 916 & 8.3997 & 1.0281 & 6.4791 & 11.1332 \\
GDP Growth & 916 & 0.0299 & 0.0464 & -0.1668 & 0.3451 \\
Territory Control & 940 & 91.7064 & 8.3743 & 48 & 100 \\
EF & 940 & 0.4775 & 0.2723 & 0.0001 & 0.8833 \\
Election Accepted & 940 & -0.6904 & 1.172 & -3.325 & 1.728 \\
Civil Society & 940 & 0.4615 & 0.1955 & 0.069 & 0.914 \\
Regional Polyarchy & 940 & 0.3444 & 0.1221 & 0.1256 & 0.721 \\
Post-Cold War & 940 & 0.6734 & 0.4692 & 0 & 1 \\
\hline
\end{tabular}

Oil production per capita and district magnitude could also be included in our models as rent capacity can facilitate more effective cooptation and repression, while modifications to the electoral system could mechanically alter the seat distribution between parties. Moreover, "western leverage" (Levitsky and Way 2006) in the form of foreign aid may push authoritarian regimes towards democratization. However, the use of associated variables would force us to drop a significant number of our observations due to missing data. Thus, while we do not include such variables in our main models, we show that our results are robust to their inclusion in the appendix.

\section{Results}

Table 2 presents the results of the logistic (Model 1) and multinomial logistic (Model 2) regressions using system-level electoral volatility as the key independent variable. The 
remaining results presented in Tables 3, 4, and 5 use our disaggregated measures of electoral volatility. Given that estimates of the control variables are generally similar across the board, only Table 2 reports the full results, and the results for the control variables in Table 3, 4, and 5 are presented in Appendix A.

Table 2

\begin{tabular}{|c|c|c|c|c|}
\hline Model & (1) & & (2) & \\
\hline $\begin{array}{c}\text { Comparison Group } \\
\text { vs. } \\
\text { Reference Group }\end{array}$ & $\begin{array}{c}\text { Breakdown } \\
\text { vs. } \\
\text { Survival }\end{array}$ & $\begin{array}{c}\text { Replacement } \\
\text { vs. } \\
\text { Survival }\end{array}$ & $\begin{array}{c}\text { Democracy } \\
\text { vs. } \\
\text { Survival }\end{array}$ & $\begin{array}{c}\text { Democracy } \\
\text { vs. } \\
\text { Replacement }\end{array}$ \\
\hline$E V$ & $\begin{array}{c}0.0137 \\
(0.0119)\end{array}$ & $\begin{array}{l}-0.0025 \\
(0.0122)\end{array}$ & $\begin{array}{c}0.0524 * * \\
(0.0239)\end{array}$ & $\begin{array}{c}0.0549 * * \\
(0.0262)\end{array}$ \\
\hline Regime Age & $\begin{array}{c}-0.261)^{*} \\
(0.1509)\end{array}$ & $\begin{array}{c}-0.5421 * * * \\
(0.1668)\end{array}$ & $\begin{array}{c}0.3868 \\
(0.2543)\end{array}$ & $\begin{array}{c}0.9289 * * * \\
(0.3134)\end{array}$ \\
\hline Years Since Election & $\begin{array}{c}0.1392 \\
(0.1008)\end{array}$ & $\begin{array}{c}0.3468^{* * *} \\
(0.1215)\end{array}$ & $\begin{array}{l}-0.3373 \\
(0.2214)\end{array}$ & $\begin{array}{c}-0.6841^{* * *} \\
(0.2544)\end{array}$ \\
\hline ENP (ln) & $\begin{array}{c}0.3357 \\
(0.4300)\end{array}$ & $\begin{array}{c}0.6271 \\
(0.4883)\end{array}$ & $\begin{array}{l}-0.2220 \\
(0.7093)\end{array}$ & $\begin{array}{l}-0.8491 \\
(0.8174)\end{array}$ \\
\hline GDP per capita (In) & $\begin{array}{c}-0.3030^{*} \\
(0.1824)\end{array}$ & $\begin{array}{l}-0.4308^{*} \\
(0.2294)\end{array}$ & $\begin{array}{l}-0.0993 \\
(0.3621)\end{array}$ & $\begin{array}{c}0.3315 \\
(0.4343)\end{array}$ \\
\hline GDP Growth & $\begin{array}{l}-2.9421 \\
(3.7142)\end{array}$ & $\begin{array}{l}-6.0545 \\
(4.0032)\end{array}$ & $\begin{array}{c}2.2353 \\
(5.9220)\end{array}$ & $\begin{array}{c}8.2898 \\
(6.5171)\end{array}$ \\
\hline Territory Control & $\begin{array}{l}-0.0123 \\
(0.0124)\end{array}$ & $\begin{array}{l}-0.0158 \\
(0.0144)\end{array}$ & $\begin{array}{c}0.0183 \\
(0.0215)\end{array}$ & $\begin{array}{c}0.0341 \\
(0.0260)\end{array}$ \\
\hline$E F$ & $\begin{array}{l}-0.7928 \\
(0.5417)\end{array}$ & $\begin{array}{l}-1.0713^{*} \\
(0.6240)\end{array}$ & $\begin{array}{c}0.1518 \\
(0.9697)\end{array}$ & $\begin{array}{c}1.2231 \\
(1.0866)\end{array}$ \\
\hline Election Accepted & $\begin{array}{c}0.3705^{* *} \\
(0.1544)\end{array}$ & $\begin{array}{c}0.2342 \\
(0.1618)\end{array}$ & $\begin{array}{c}0.9447 * * * \\
(0.3154)\end{array}$ & $\begin{array}{l}0.7106^{* *} \\
(0.3339)\end{array}$ \\
\hline Civil Society & $\begin{array}{c}1.7353^{* *} \\
(0.8396)\end{array}$ & $\begin{array}{c}0.8368 \\
(1.0301)\end{array}$ & $\begin{array}{c}4.4984^{* *} \\
(1.7472)\end{array}$ & $\begin{array}{l}3.6616^{*} \\
(2.0656)\end{array}$ \\
\hline Regional Polyarchy & $\begin{array}{c}3.8977 * * * \\
(1.2400)\end{array}$ & $\begin{array}{c}1.8759 \\
(1.6318)\end{array}$ & $\begin{array}{c}7.7837^{* * *} \\
(2.1496)\end{array}$ & $\begin{array}{l}5.9078^{* *} \\
(2.7213)\end{array}$ \\
\hline Post-Cold War & $\begin{array}{c}-0.6218^{*} \\
(0.3663)\end{array}$ & $\begin{array}{l}-0.5946 \\
(0.4577)\end{array}$ & $\begin{array}{l}-0.7807 \\
(0.6849)\end{array}$ & $\begin{array}{l}-0.1861 \\
(0.8803)\end{array}$ \\
\hline Constant & $\begin{array}{c}0.1159 \\
(2.2935)\end{array}$ & $\begin{array}{c}3.0119 \\
(2.8861)\end{array}$ & $\begin{array}{c}-11.4722^{* *} \\
(4.4753)\end{array}$ & $\begin{array}{c}-14.4840^{* * *} \\
(5.5543)\end{array}$ \\
\hline $\begin{array}{c}N \\
\text { Pseudo R }\end{array}$ & $\begin{array}{c}916 \\
0.1349\end{array}$ & & $\begin{array}{c}916 \\
0.1895\end{array}$ & \\
\hline
\end{tabular}

Note: results report country-clustered standard errors. The model also includes cubic polynomials of a time trend variable to model temporal dependence as proposed by Carter and Signorino (2010).

${ }^{*} p<0.10 ; * * p<0.05 ; * * * p<0.01$.

As expected, the results of Model 1 indicate that system-level electoral volatility does not seem to be associated with regime breakdown in general. ${ }^{13}$ However, Model 2

\footnotetext{
13 As for the control variables, competitive authoritarian regimes are less likely to be replaced by another authoritarian regime as they become older, GDP per capita is higher, and when ethnic fractionalization is greater. Authoritarian replacement becomes more likely while democratization becomes less likely as more time passes since the last election. Democratization becomes more likely when the opposition accepts the most recent election results, there is a vibrant civil society, and when surrounding countries are more democratic.
} 
shows that the association between regime stability and electoral volatility is more nuanced. As with democracies, competitive authoritarian regimes may be more vulnerable when party systems are under-institutionalized, though this figures strongly in cases of democratic transition and not authoritarian replacement.

Table 3

\begin{tabular}{|c|c|c|c|c|}
\hline Model & (3) & & (4) & \\
\hline $\begin{array}{c}\text { Comparison Group } \\
\text { vs. } \\
\text { Reference Group }\end{array}$ & $\begin{array}{c}\text { Breakdown } \\
\text { vs. } \\
\text { Survival } \\
\end{array}$ & $\begin{array}{c}\text { Replacement } \\
\text { vs. } \\
\text { Survival } \\
\end{array}$ & $\begin{array}{c}\text { Democracy } \\
\text { vs. } \\
\text { Survival } \\
\end{array}$ & $\begin{array}{c}\text { Democracy } \\
\text { vs. } \\
\text { Replacement }\end{array}$ \\
\hline $\begin{array}{l}\text { RPSC } \\
\text { OPV }\end{array}$ & $\begin{array}{c}0.0100 \\
(0.0099) \\
0.0180 \\
(0.0148)\end{array}$ & $\begin{array}{c}0.0107 \\
(0.0111) \\
0.0016 \\
(0.0145)\end{array}$ & $\begin{array}{c}0.0037 \\
(0.0185) \\
0.0592^{*} \\
(0.0316)\end{array}$ & $\begin{array}{l}-0.0069 \\
(0.0197) \\
0.0576^{*} \\
(0.0323)\end{array}$ \\
\hline $\begin{array}{c}N \\
\text { Pseudo R }{ }^{2}\end{array}$ & $\begin{array}{c}916 \\
0.1382\end{array}$ & & $\begin{array}{c}916 \\
0.1893\end{array}$ & \\
\hline
\end{tabular}

Note: results report country-clustered standard errors. Full results are presented in Appendix A.

${ }^{*} p<0.10 ; * * p<0.05 ; * * * p<0.01$.

Table 4

\begin{tabular}{|c|c|c|c|c|}
\hline Model & (5) & & (6) & \\
\hline $\begin{array}{c}\text { Comparison Group } \\
\text { vs. } \\
\text { Reference Group }\end{array}$ & $\begin{array}{c}\text { Breakdown } \\
\text { vs. } \\
\text { Survival } \\
\end{array}$ & $\begin{array}{c}\text { Replacement } \\
\text { vs. } \\
\text { Survival } \\
\end{array}$ & $\begin{array}{c}\text { Democracy } \\
\text { vs. } \\
\text { Survival } \\
\end{array}$ & $\begin{array}{c}\text { Democracy } \\
\text { vs. } \\
\text { Replacement }\end{array}$ \\
\hline RPSC & $\begin{array}{c}0.0089 \\
(0.0101)\end{array}$ & $\begin{array}{c}0.0126 \\
(0.0113)\end{array}$ & $\begin{array}{l}-0.0072 \\
(0.0211)\end{array}$ & $\begin{array}{l}-0.0198 \\
(0.0225)\end{array}$ \\
\hline$O P V-A$ & $\begin{array}{c}0.0170 \\
(0.0151)\end{array}$ & $\begin{array}{c}0.0044 \\
(0.0140)\end{array}$ & $\begin{array}{l}0.0623^{*} \\
(0.0362)\end{array}$ & $\begin{array}{c}0.0579 \\
(0.0368)\end{array}$ \\
\hline$O P V-B$ & $\begin{array}{c}0.0327 \\
(0.0318)\end{array}$ & $\begin{array}{l}-0.0281 \\
(0.0411)\end{array}$ & $\begin{array}{c}0.1619^{* * *} \\
(0.0484)\end{array}$ & $\begin{array}{c}0.1900^{* * *} \\
(0.0620)\end{array}$ \\
\hline $\begin{array}{c}N \\
\text { Pseudo } \mathrm{R}^{2}\end{array}$ & $\begin{array}{c}916 \\
0.1387\end{array}$ & & $\begin{array}{c}916 \\
0.1964\end{array}$ & \\
\hline
\end{tabular}

Note: results report country-clustered standard errors. Full results are presented in Appendix A.

${ }^{*} p<0.10 ; * * p<0.05 ;{ }^{* * *} p<0.01$.

Table 3 replaces system-level electoral volatility with ruling party seat change and opposition party volatility, and we further distinguish between Type-A and Type-B opposition party volatility in Table 4 . The results suggest that ruling party seat change does not seem to be linked to any form of regime breakdown, and while opposition party Type-A volatility achieves statistical significance in Model 6 and in several of our other models, our robustness checks reveal that this outcome can be sensitive to model specification and/or dropping influential cases. Our main (and robust) finding is that opposition party Type-B volatility is associated with a higher likelihood of democratization (Model 6, Table 4). This aligns with our argument that the ability of the ruling party to manage key opposition parties and supporters through elections is particularly important for their survival, and this pattern runs entirely counter to understandings of electoral 
volatility in democracies, in which Type-A volatility is thought to be more detrimental to regime stability than Type-B volatility.

To examine whether opposition party Type-B volatility is more dangerous for ruling parties when they suffer electoral setbacks, we re-estimate the models in Table 4 adding an interaction term between RPSC and opposition party OPV-B. ${ }^{14}$ Estimates of the coefficients of interest are presented in Table 5.

Table 5

\begin{tabular}{|c|c|c|c|c|}
\hline Model & (7) & & (8) & \\
\hline $\begin{array}{c}\text { Comparison Group } \\
\text { vs. } \\
\text { Reference Group }\end{array}$ & $\begin{array}{c}\text { Breakdown } \\
\text { vs. } \\
\text { Survival }\end{array}$ & $\begin{array}{c}\text { Replacement } \\
\text { vs. } \\
\text { Survival }\end{array}$ & $\begin{array}{c}\text { Democracy } \\
\text { vs. } \\
\text { Survival }\end{array}$ & $\begin{array}{c}\text { Democracy } \\
\text { vs. } \\
\text { Replacement }\end{array}$ \\
\hline RPSC & $\begin{array}{l}0.0236^{*} \\
(0.0125)\end{array}$ & $\begin{array}{c}0.0138 \\
(0.0122)\end{array}$ & $\begin{array}{c}0.0350 \\
(0.0287)\end{array}$ & $\begin{array}{c}0.0212 \\
(0.0303)\end{array}$ \\
\hline$O P V-A$ & $\begin{array}{c}0.0174 \\
(0.0152)\end{array}$ & $\begin{array}{c}0.0043 \\
(0.0140)\end{array}$ & $\begin{array}{l}0.0726^{*} \\
(0.0373)\end{array}$ & $\begin{array}{l}0.0683^{*} \\
(0.0377)\end{array}$ \\
\hline$O P V-B$ & $\begin{array}{c}0.0461 \\
(0.0341)\end{array}$ & $\begin{array}{l}-0.0259 \\
(0.0437)\end{array}$ & $\begin{array}{c}0.2070^{* * *} \\
(0.0647)\end{array}$ & $\begin{array}{c}0.2329 * * * \\
(0.0771)\end{array}$ \\
\hline$R P S C \times O P V-B$ & $\begin{array}{c}-0.0029 * * \\
(0.0011)\end{array}$ & $\begin{array}{l}-0.0002 \\
(0.0016)\end{array}$ & $\begin{array}{c}-0.0076 * * * \\
(0.0025)\end{array}$ & $\begin{array}{c}-0.0073 * * \\
(0.0032)\end{array}$ \\
\hline $\begin{array}{c}N \\
\text { Pseudo } \mathrm{R}^{2}\end{array}$ & $\begin{array}{c}916 \\
0.1458\end{array}$ & & $\begin{array}{c}916 \\
0.2106\end{array}$ & \\
\hline
\end{tabular}

Note: results report country-clustered standard errors. Full results are presented in Appendix A.

${ }^{*} p<0.10 ;{ }^{* *} p<0.05 ;{ }^{* * *} p<0.01$.

To facilitate interpretation of the interaction, we plot the predicted probability of democratic transition along with 90 percent confidence intervals across the range of observed $O P V-B$ values when values of RPSC are held at \pm 1 standard deviation from the mean of RPSC (around -13 and 16), and other variables are held their means. The plot is shown in Figure 3.

The likelihood of democratic transition is largely unaffected by increased Type-B opposition volatility when the ruling party improves on its past electoral performance. However, when the ruling party loses a relatively significant share of seats and Type-B opposition volatility begins to exceed its mean value (4.11), the predicted probability of regime breakdown via democratization begins to grow substantially, and when it hits the maximum value in our sample (22.95), the predicted probability of democratic transition becomes quite large (around 0.53). Such electoral dynamics align with the conceding-to-thrive scenario described by Slater and Wong (2013), in which ruling parties accept democratization when they face "ominous setbacks signaling that they have passed their apex of domination," and turn their attention from maintaining an authoritarian

\footnotetext{
${ }^{14}$ Interactions between ruling party seat change and opposition party Type-A volatility do not generate any robust and substantively meaningful results. As such, we do not include the interactions in our analysis.
} 
collusive equilibrium to leveraging their political and resource advantages to win democratic elections.

Figure 3. Predicted Probability of Democratization

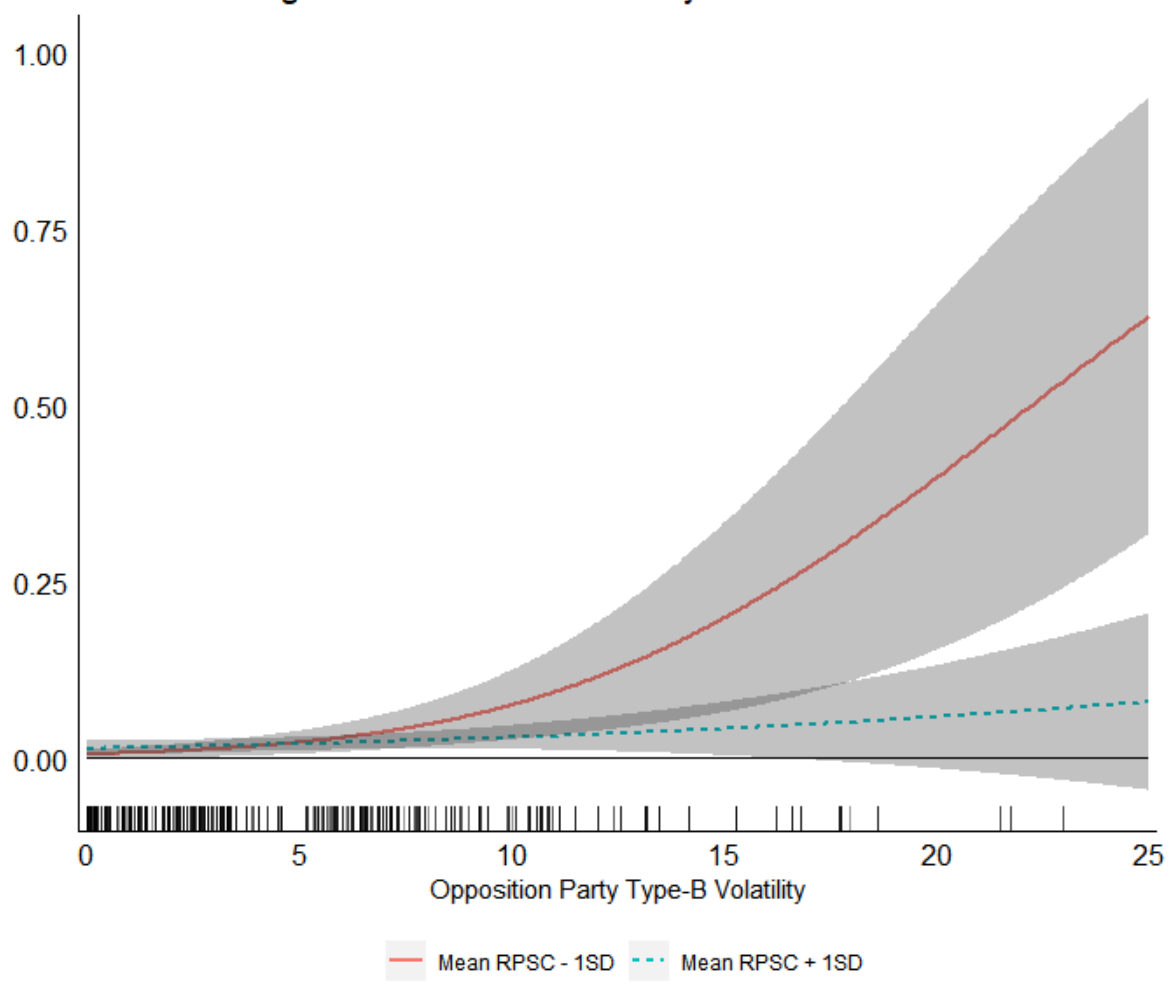

\section{Robustness Checks}

We conduct several robustness checks, which are presented in the appendix, to address concerns that our results might be driven by omitted variable bias or influential cases. For parsimony, we focus on Models 7 and 8 presented in Table 5, and specifically on the coefficient estimates of RPSC, OPV-B, and their interaction given that they are the strongest predictors of the likelihood of regime failure.

In Appendix B, we include oil production per capita as a measure of rent capacity using data from Ross and Mahdavi (2015) supplemented by Wimmer and Min (2006), although this reduces our sample by 129 observations. In Appendix C, we add a variable that measures the change in district magnitude across two consecutive elections since volatility in seat shares may also be driven by institutional changes. We use district magnitude data from the Database of Political Institutions (Cruz, Keefer, and Scartascini 2018), though the inclusion of the variable causes us to lose around a third of our observations. In Appendix D, we account for Official Development Assistance (ODA), or foreign aid, that countries receive from the Development Assistance Committee-which is principally composed of developed democracies- to capture the 
extent to which incumbents are exposed to external pressure for democratization, i.e., the degree of "western leverage" (Levitsky and Way 2006). The data is available from the OECD (2021), though only from 1960 onwards and thus we lose 108 observations from our sample. In Appendix $\mathrm{E}$, we use the original ethnic fractionalization scores calculated from the CREG data set, i.e., without linear prediction and substitution. This drops around a fifth of our observations. In Appendix F, we drop censored regimes that were still in power as of 2018, which leaves us with around 60 percent of our sample. As shown in the appendices, the estimated relationships between RPSC, OPV-B, and the probability of democratization remain robust and statistically significant, although a few estimates become noisier due to reduced sample sizes.

Adding all the control variables to our model and using just the original CREG-based ethnic fractionalization scores would cause us to lose more than half of our sample. As such, we re-estimate this full model after using Multiple Imputation by Chained Equations (MICE) to impute missing values based on observed values of our variables. We impute 10 complete data sets and present the pooled estimates in Appendix G. The results remain robust.

Lastly, there may be concerns that our results could be driven by a single influential regime. To address these concerns, we re-estimate Model 8 in Table 5 dropping one country at a time. This presents a more challenging test of robustness since more than one regime may be dropped when a country is excluded from the sample. As shown in Appendix $\mathrm{H}$, our results are not driven by one influential case.

\section{Conclusion}

The collapse of many conventional authoritarian regimes over the past several decades has been accompanied by the rise of authoritarian regimes that hold competitive multiparty elections. The literature argues that the holding of elections was a strategic move designed to enhance the viability of authoritarianism in the face of a global surge in democratization. While the empirical evidence in support of this is at best mixed, we argue that the success of electoral authoritarian regimes depends crucially on the ability of ruling parties to legitimize and extend their rule by effectively managing elections and the opposition. We adapt the concept of party system institutionalization from its use in the study democracies to capture the specificities of electoral competition under authoritarianism. Rather than focusing on whether competitive elections fortify or undermine authoritarian rule, we explain regime durability/vulnerability as a product of the skills of the authoritarian incumbent to resolve electoral uncertainty and establish an institutionalized party system. 
To test our claim, we explore the relationship between electoral volatility, the most commonly used measure of party system institutionalization, and the survival of competitive authoritarian regimes. Because elections in competitive authoritarian regimes revolve around the ruling party and thus follow a different logic than democracies, we examine both ruling party seat change and opposition party volatility. We find evidence that the ability of the ruling party to control electoral outcomes by maintaining a collusive equilibrium with the opposition is critical for regime survival. Moreover, the consequences of party system institutionalization for regime stability in competitive authoritarian regimes contrast with those in democracies, as the results show a robust association between Type-B volatility (but not Type-A volatility) and regime breakdown via democratization. Since measures of electoral volatility tend to be noisy (Casal Bértoa, Deegan-Krause, and Haughton. 2017), the fact that our analyses capture significant and robust associations lends evidence to our argument that electoral outcomes do provide meaningful information about the survival and breakdown of ruling parties in competitive authoritarian regimes.

The findings of this paper show that an increased focus on the institutionalization of party systems in authoritarian contexts is warranted, and corroborate existing arguments that elections can pave the way toward democratization in competitive authoritarian regimes. We show that the ability of the incumbent to manage elections holds one of the keys to success or failure. The fact that our findings on breakdown seem to be driven by democratization more than authoritarian replacement is a reminder that the conditions under which the latter occurs requires more study. But we can say that the ability of the incumbent to manage the electoral sphere does not seem to play are large role in neo-autocratization. 


\section{References}

Alesina, Alberto, Arnaud Devleeschauwer, William Easterly, Sergio Kurlat, and Romain Wacziarg. (2003). "Fractionalization.” Journal of Economic Growth 8(2): 155-94.

Arriola, Leonardo R., Jed Devaro, and Anne Meng. (2021). "Democratic Subversion: Elite Cooptation and Opposition Fragmentation." American Political Science Review 115(4): 135872.

Bartolini, Stefano, and Peter Mair. (1990). Identity, Competition and Electoral Availability. The Stabilization of European Electorates 1885-1985. Cambridge: Cambridge University Press.

Bernhard, Michael, Allen Hicken, Christopher Reenock, and Staffan I. Lindberg. (2020). "Parties, Civil Society, and the Deterrence of Democratic Defection," Studies in Comparative International Development 55(1): 1-21.

Bernhard, Michael, Amanda Edgell, and Staffan I. Lindberg. (2020). "Institutionalising Electoral Uncertainty and Authoritarian Regime Survival.” European Journal of Political Research 59(2): 465-487.

Bernhard, Michael and Ekrem Karakoç. (2011). "Moving West or going South? Economic Transformation and Institutionalization in Post-communist Party Systems." Comparative Politics, 44(1): 1-20.

Bielasiak, Jack. (2002). "The Institutionalization of Electoral and Party Systems in Postcommunist States," Comparative Politics 34(2): 189-210.

Bielasiak, Jack. (2005). "Party Competition in Emerging Democracies.” Democratization 12(3): $331-56$.

Boix, Carles, and Milan W. Svolik. (2013). "The Foundations of Limited Authoritarian Government: Institutions, Commitment, and Power-sharing in Dictatorships." Journal of Politics 75(2): 300-16.

Boix, Carles, Michael Miller, and Sebastian Rosato. (2012). "A Complete Data set of Political Regimes, 1800-2007." Comparative Political Studies 46(12): 1523-54.

Bolt, Jutta, and Jan Luiten van Zanden. (2020). "Maddison Style Estimates of the Evolution of the World Economy. A New 2020 Update.” Maddison Project Working Paper 15.

Bunce, Valerie, and Sharon L. Wolchik. (2011). Defeating Authoritarian Leaders in Postcommunist Countries. Cambridge: Cambridge University Press.

Carter, David B., and Curtis S. Signorino. (2010). "Back to the Future: Modeling Time Dependence for Binary Data.” Political Analysis. 18(3): 272-92.

Casal Bértoa, Fernando, Kevin Deegan-Krause, and Tim Haughton. (2017). "The Volatility of Volatility: Measuring Change in Party Vote Shares.” Electoral Studies 50: 142-56.

Casal Bértoa, Fernando, and Zsolt Enyedi. (2021). Party System Closure, Party Alliances, Government Alternatives, and Democracy in Europe. Oxford University Press. 
Cohen, Mollie J., Facundo E. Salles Kobilanski, and Elizabeth J. Zechmeister. (2018). "Electoral Volatility in Latin America." Journal of Politics 80(3): 1017-22.

Coppedge, Michael, John Gerring, Carl Henrik Knutsen, Staffan I. Lindberg, Jan Teorell, David Altman, Michael Bernhard, M. Steven Fish, Adam Glynn, Allen Hicken, Anna Lührmann, Kyle L. Marquardt, Kelly McMann, Pamela Paxton, Daniel Pemstein, Brigitte Seim, Rachel Sigman, Svend-Erik Skaaning, Jeffrey Staton, Steven Wilson, Agnes Cornell, Nazifa Alizada, Lisa Gastaldi, Haakon Gjerløw, Garry Hindle, Nina Ilchenko, Laura Maxwell, Valeriya Mechkova, Juraj Medzihorsky, Johannes von Römer, Aksel Sundström, Eitan Tzelgov, Yi-ting Wang, Tore Wig, and Daniel Ziblatt. 2020. "V-Dem [Country-Year/Country-Date] Dataset v10." Varieties of Democracy (V-Dem) Project.

Coppedge, Michael, John Gerring, Carl Henrik Knutsen, Staffan I. Lindberg, Jan Teorell, David Altman, Michael Bernhard, M. Steven Fish, Adam Glynn, Allen Hicken, Anna Lührmann, Kyle L. Marquardt, Kelly McMann, Pamela Paxton, Daniel Pemstein, Brigitte Seim, Rachel Sigman, Svend-Erik Skaaning, Jeffrey Staton, Agnes Cornell, Lisa Gastaldi, Haakon Gjerløw, Valeriya Mechkova, Johannes von Römer, Aksel Sundtröm, Eitan Tzelgov, Luca Uberti, Yi-ting Wang, Tore Wig, and Daniel Ziblatt. (2020). "V-Dem Codebook v10." Varieties of Democracy (V-Dem) Project.

Cruz, Cesi, Philip Keefer, and Carlos Scartascini. (2018). “The Database of Political Institutions.” Washington: Inter-American Development Bank.

Easterly, William, and Ross Levine. (1997). “Africa's Growth Tragedy: Policies and Ethnic Divisions." Quarterly Journal of Economics 112(4): 1203-50.

Gandhi, Jennifer, and Adam Przeworski. (2007). "Authoritarian Institutions and the Survival of Autocrats." Comparative Political Studies 40(11): 1279-301.

Geddes, Barbara, Joseph Wright, and Erica Frantz. (2014). "Autocratic Breakdown and Regime Transitions: A New Data set." Perspectives on Politics 12(2): 313-31.

Geddes, Barbara, Joseph Wright, and Erica Frantz. (2018). How Dictatorships Work: Power, Personalization, and Collapse. Cambridge: Cambridge University Press.

Greene, Kenneth F. (2010). "The Political Economy of Authoritarian Single-party Dominance." Comparative Political Studies 43(7): 807-34.

Haughton, Tim and Kevin Deegan-Krause. (2020). The New Party Challenge Changing Cycles of Party Birth and Death in Central Europe and Beyond. New York: Oxford University Press.

Havel, Václav. (2018). “The Power of the Powerless.” East European Politics and Societies 32(2): 353-408.

Helmke, Gretchen. (2010). "The Origins of Institutional Crises in Latin America." American Journal of Political Science 54(3): 737-50.

Helmke, Gretchen. (2017). Institutions on the Edge: The Origins and Consequences of Inter-branch Crises in Latin America. New York: Cambridge University Press.

Hicken, Allen. (2018). "Party Systems and the Politics of Development.” In Carol Lancaster and 
Nicolas van de Walle (eds.), Handbook on the Politics of Development. New York: Oxford University Press.

Hicken, Allen, and Erik M. Kuhonta. (2011). "Shadows from the Past: Party System Institutionalization in Asia." Comparative Political Studies 44(5): 572-97.

Hicken, Allen, and Erik M. Kuhonta. (2014). "Rethinking Party System Institutionalization in Asia." In Allen Hicken and Erik Kuhonta (eds.), Party and Party System Institutionalization in Asia. New York: Cambridge University Press.

Hooghe, Liesbeth, and Gary Marks. (2018). "Cleavage Theory Meets Europe's Crises: Lipset, Rokkan and the Transnational Cleavage." Journal of European Public Policy 25(1): 109-135.

Horowitz, Donald L. (1993). "The Challenge of Ethnic Conflict: Democracy in Divided Societies." Journal of Democracy 4(4): 18-38.

Inglehart, Ronald. (1977). The Silent Revolution: Changing Values and Political Styles Among Western Publics. Princeton: Princeton University Press.

Innes, Abby. (2002). "Party Competition in Postcommunist Europe: The Great Electoral Lottery." Comparative Politics 35(1): 85-104.

Kaya, Ruchan, and Michael Bernhard. (2013). "Are Elections Mechanisms of Authoritarian Stability or Democratization? Evidence from Postcommunist Eurasia." Perspectives on Politics 11(3): 734-52.

Kitschelt, Herbert. (1989). The Logic of Party Formation. Ecological Politics in Belgium and West Germany. Ithaca: Cornell University Press.

Kitschelt, Herbert, Zdenka Mansfeldova, Radosław Markowski, and Gábor Tóka. (1999). PostCommunist Party Systems: Competition, Representation, and Inter-Party Competition. Cambridge: Cambridge University Press.

Knutsen, Carl Henrik, Håvard Mokleiv Nygård, and Tore Wig. (2017). “Autocratic Elections: Stabilizing Tool or Force for Change?” World Politics 69(1): 98-143.

Kriesi, Hanspeter, Edgar Grande, Romain Lachat, Martin Dolezal, Simon Bornschier, and Timotheos Frey. (2008). West European Politics in the Age of Globalization. Cambridge: Cambridge University Press.

Kuenzi, Michelle, and Gina M. Lambright. (2005). "Party Systems and Democratic Consolidation in Africa's Electoral Regimes." Party Politics, 11(4): 423-46.

Levitsky, Steven, and Lucan Way. (2006). "Linkage verses Leverage.” Comparative Politics 38(4): 379-400.

Levitsky, Steven, and Lucan Way. (2010). Competitive Authoritarianism: Hybrid Regimes After the Cold $W$ ar. New York: Cambridge University Press. 
Lührmann, Anna, Marcus Tannenberg, and Staffan I. Lindberg (2018). "Regimes of the World (RoW): Opening New Avenues for the Comparative Study of Political Regimes." Politics and Governance 6(1):60-77.

Lupu, Noam, and Susan Stokes. (2010). "Democracy, Interrupted: Regime Change and Partisanship in Twentieth-Century Argentina." Electoral Studies 29: 91-104.

Lust-Okar, Ellen. (2009). "Legislative Elections in Hegemonic Authoritarian Regimes: Competitive Clientelism and Resistance to Democratization.” In Lindberg, Staffan I. (ed.), Democratization by Elections: a New Mode of Transition. Baltimore: Johns Hopkins University Press. 226-45.

Lipset, Seymour Martin, and Stein Rokkan, Stein. (1967). "Cleavage Structures, Party Systems, and Voter Alignments: an Introduction." Party Systems and Voter Alignments: Cross-National Perspectives. New York, Free Press. 1-64.

Madrid, Raúl. (2005). "Ethnic Cleavages and Electoral Volatility in Latin America." Comparative Politics 38(1): 1-20.

Magaloni, Beatriz. (2008). "Credible Power-sharing and the Longevity of Authoritarian Rule." Comparative Political Studies 41(4-5): 715-41.

Magaloni, Beatriz. (2010). "The Game of Electoral Fraud and the Ousting of Authoritarian Rule." American Journal of Political Science 54(3): 751-65.

Mainwaring, Scott. (1999). "Party System Institutionalization, Party Collapse and Party Building." Government and Opposition 51(4): 691-716.

Mainwaring, Scott, and Timothy Scully. (1995). "Introduction: Party Systems in Latin America." in Scott Mainwaring and Timothy Scully (eds.), Building Democratic Institutions: Party Systems in Latin America Stanford, CA: Stanford University Press. 1-36.

Mainwaring, Scott, and Edume Zoco, E. (2007). "Political Sequences and the Stabilization of Interparty Competition: Electoral Volatility in Old and New Democracies." Party Politics 13(2): 155-78.

Mann, Michael. (1984). "The Autonomous Power of the State: Its Origins, Mechanism and Results.” European Journal of Sociology 25(2): 185-213.

Morgan, Jana. (2011). Bankrupt Representation and Party System Collapse. University Park: Pennsylvania State University Press.

Mozaffar, Shaheen, James R. Scarritt, and Glen Galaich. (2003). "Electoral Institutions, Ethnopolitical Cleavages, and Party Systemsin Africa's Emerging Democracies." American Political Science Review 97(3): 379-90.

Nardulli, Peter F., Cara J. Wong, Ajay Singh, Buddy Peyton, and Joseph Bajjalieh. (2012). The Composition of Religious and Ethnic Groups (CREG) Project. Urbana, IL: Cline Center for Democracy, University of Illinois Urbana-Champaign.

Newton, Kenneth (2001). “Trust, Social Capital, Civil Society, and Democracy.” International 
Political Science Review 22(2): 201-14.

OECD. (2021). OECD Data. Retrieved from https://data.oecd.org/

Pedersen, Mogens N. (1979). "The Dynamics of European Party Systems: Changing Patterns of Electoral Volatility.” European Journal of Political Research 7.1: 1-26.

Pemstein, Daniel, Kyle L. Marquardt, Eitan Tzelgov, Yi-ting Wang, Juraj Medzihorsky, Joshua Krusell, Farhad Miri, and Johannes von R"omer. 2020. "The V-Dem Measurement Model: La-tent Variable Analysis for Cross-National and Cross-Temporal Expert-Coded Data". V-Dem Working Paper No. 21. 5th edition. University of Gothenburg: Varieties of Democracy Institute.

Powell, Elearnor Neff and Joshua A. Tucker. (2014). "Revisiting Electoral Volatility in PostCommunist Countries: New Data, New Results and New Approaches." British Journal of Political Science 44(1): 123-47.

Przeworski, Adam. (1991). Democracy and Market: Political and Economic Reforms in Eastern Europe and Latin America. Cambridge: Cambridge University Press.

Riedl, Rachel B. (2014). Authoritarian Origins of Democratic Party Systems: Power in Transition in Africa. Cambridge: Cambridge University Press.

Roberts, Kenneth M. (2014). Changing Course in Latin America: Party Systems in the Neoliberal Era. New York: Cambridge University Press.

Roberts, Kenneth M. and Erik Wibbles. (1999). "Party Systems and Electoral Volatility in Latin America: A Test of Economic, Institutional, and Structural Explanations." American Political Science Review 93(3): 575-90.

Rose, Richard and Derek Urwin. (1970). "Persistence and Change in Western Party Systems since 1945." Political Studies 18(3): 287-319.

Ross, Michael L. and Paasha Madhavi. (2015). Oil and Gas Data, 1932-2014, Version 2. Available online at: https://doi.org/10.7910/DVN/ZTPW0Y

Sartori, Giovanni. (1976). Parties and Party Systems. Cambridge: Cambridge University Press.

Schedler, Andreas. (200b). "Elections Without Democracy: The Menu of Manipulation." Journal of Democracy 13(2): 36-50.

Schleiter, Petra, and Alisa Voznaya. (2016). "Party System Institutionalization, Accountability and Governmental Corruption." British Journal of Political Science 48(2): 315-42.

Seawright, Jason. (2012). Party-System Collapse: The Roots of Crisis in Peru and Venequela. Palo Alto, CA: Stanford University Press.

Slater, Dan. (2008). "Can Leviathan be Democratic? Competitive Elections, Robust Mass Politics, and State Infrastructural Power," Studies in Comparative International Development 43(3-4): 252-72. 
Smith, Benjamin. (2007). Hard Times in the Lands of Plenty: Oil Politics in Iran and Indonesia. Ithaca, NY: Cornell University Press.

Stockton, Hans. (2001) "Political Parties, Party Systems, and Democracy in East Asia." Comparative Political Studies 34 (1): 94-119.

Stokes, Susan C. (2001). Mandates and Democracy: Neoliberalism by Surprise in Latin America. New York: Cambridge University Press.

Svolik, Milan.W. (2012). The Politics of Authoritarian Rule. New York: Cambridge University Press.

Tavits, Margit. (2005). "The Development of Stable Party Support: Electoral Dynamics in Postcommunist Europe." American Journal of Political Science 49(2): 283-98.

Tucker, Joshua. (2007). "Enough! Electoral Fraud, Collective Action Problems, and PostCommunist Colored Revolutions." Perspectives on Politics 5(3): 537-553.

Ufen, Andreas. (2013). "Lipset and Rokkan in Southeast Asia: Indonesia in Comparative Perspective." In Dirk Tomsa and Andres Ufen (eds.), Party Politics in Southeast Asia: Clientelism and Electoral Competition in Indonesia, Thailand and the Philippines. Abingdon: Routledge. 40-61

Weghorst, Keith R., and Michael Bernhard. (2014). "From Formlessness to Structure? The Institutionalization of Competitive Party Systems in Africa." Comparative Political Studies 47(12): 1707-37.

Wilkinson, Steven I. (2015). "Where's the Party? The Decline of Party Institutionalization and What (If Anything) That Means for Democracy." Government and Opposition 50(3): 420-45.

Wimmer, Andres, and Brian Min. (2006). "From Empire to Nation-State: Explaining Wars in the Modern World, 1816-2001.” American Sociological Review 71(6): 867-97.

Wright, Joseph, and Abel Escribà-Folch. (2012). "Authoritarian Institutions and Regime Survival: Transitions to Democracy and Subsequent Autocracy." British Journal of Political Science, 42(2): 283-309.

Zaslavsky, Viktor, and Robert J. Brym. (1978). "The Functions of Elections in the USSR." Soviet Studies 30(3): 362-71. 
Appendix A: Full results of Tables 3, 4, 5

Table 3

\begin{tabular}{|c|c|c|c|c|}
\hline Model & (1) & & (2) & \\
\hline $\begin{array}{c}\text { Comparison Group } \\
\text { vs. } \\
\text { Reference Group }\end{array}$ & $\begin{array}{c}\text { Breakdown } \\
\text { vs. } \\
\text { Survival }\end{array}$ & $\begin{array}{c}\text { Replacement } \\
\text { vs. } \\
\text { Survival }\end{array}$ & $\begin{array}{c}\text { Democracy } \\
\text { vs. } \\
\text { Survival }\end{array}$ & $\begin{array}{l}\text { Democracy } \\
\text { vs. } \\
\text { Replacement }\end{array}$ \\
\hline RPSC & $\begin{array}{c}0.0100 \\
(0.0099)\end{array}$ & $\begin{array}{c}0.0107 \\
(0.0111)\end{array}$ & $\begin{array}{c}0.0037 \\
(0.0185)\end{array}$ & $\begin{array}{l}-0.0069 \\
(0.0197)\end{array}$ \\
\hline$O P V$ & $\begin{array}{c}0.0180 \\
(0.0148)\end{array}$ & $\begin{array}{c}0.0016 \\
(0.0145)\end{array}$ & $\begin{array}{l}0.0592^{*} \\
(0.0316)\end{array}$ & $\begin{array}{l}0.0576^{*} \\
(0.0323)\end{array}$ \\
\hline Regime Age & $\begin{array}{c}-0.2590^{*} \\
(0.1454)\end{array}$ & $\begin{array}{c}-0.5231 * * * \\
(0.1658)\end{array}$ & $\begin{array}{c}0.3641 \\
(0.2441)\end{array}$ & $\begin{array}{c}0.8872 * * * \\
(0.3072)\end{array}$ \\
\hline Years Since Election & $\begin{array}{c}0.1294 \\
(0.1000)\end{array}$ & $\begin{array}{c}0.3327^{* * * *} \\
(0.1205)\end{array}$ & $\begin{array}{c}-0.3616^{*} \\
(0.2191)\end{array}$ & $\begin{array}{c}-0.6943^{* * * *} \\
(0.2516)\end{array}$ \\
\hline ENP (ln) & $\begin{array}{c}0.4078 \\
(0.5075)\end{array}$ & $\begin{array}{c}0.6931 \\
(0.5534)\end{array}$ & $\begin{array}{l}-0.3397 \\
(1.0083)\end{array}$ & $\begin{array}{l}-1.0328 \\
(1.0529)\end{array}$ \\
\hline GDP per capita (ln) & $\begin{array}{c}-0.3345^{*} \\
(0.1855)\end{array}$ & $\begin{array}{c}-0.4481 * \\
(0.2327)\end{array}$ & $\begin{array}{l}-0.1488 \\
(0.3738)\end{array}$ & $\begin{array}{c}0.2993 \\
(0.4457)\end{array}$ \\
\hline GDP Growth & $\begin{array}{l}-2.8730 \\
(3.7233)\end{array}$ & $\begin{array}{l}-5.7897 \\
(3.8799)\end{array}$ & $\begin{array}{c}2.1075 \\
(6.3209)\end{array}$ & $\begin{array}{c}7.8972 \\
(6.7401)\end{array}$ \\
\hline Territory Control & $\begin{array}{l}-0.0119 \\
(0.0125)\end{array}$ & $\begin{array}{l}-0.0167 \\
(0.0146)\end{array}$ & $\begin{array}{c}0.0191 \\
(0.0231)\end{array}$ & $\begin{array}{c}0.0358 \\
(0.0272)\end{array}$ \\
\hline$E F$ & $\begin{array}{l}-0.8327 \\
(0.5427)\end{array}$ & $\begin{array}{l}-1.0950 * \\
(0.6227)\end{array}$ & $\begin{array}{c}0.1052 \\
(0.9850)\end{array}$ & $\begin{array}{c}1.2002 \\
(1.1161)\end{array}$ \\
\hline Election Accepted & $\begin{array}{c}0.3806^{* *} \\
(0.1589)\end{array}$ & $\begin{array}{c}0.2530 \\
(0.1620)\end{array}$ & $\begin{array}{c}0.9275^{* * *} \\
(0.3084)\end{array}$ & $\begin{array}{c}0.6745^{* *} \\
(0.3174)\end{array}$ \\
\hline Civil Society & $\begin{array}{c}1.8747^{* *} \\
(0.8196)\end{array}$ & $\begin{array}{c}0.8734 \\
(0.9959)\end{array}$ & $\begin{array}{c}4.6360 * * * \\
(1.6742)\end{array}$ & $\begin{array}{l}3.7626^{*} \\
(1.9846)\end{array}$ \\
\hline Regional Polyarchy & $\begin{array}{c}4.1469 * * * \\
(1.2405)\end{array}$ & $\begin{array}{c}2.2448 \\
(1.6672)\end{array}$ & $\begin{array}{c}7.8677 * * * \\
(2.0996)\end{array}$ & $\begin{array}{l}5.6229 * * \\
(2.7136)\end{array}$ \\
\hline Post-Cold War & $\begin{array}{c}-0.6831 * \\
(0.3553)\end{array}$ & $\begin{array}{l}-0.6965 \\
(0.4473)\end{array}$ & $\begin{array}{l}-0.7959 \\
(0.6665)\end{array}$ & $\begin{array}{l}-0.0994 \\
(0.8478)\end{array}$ \\
\hline Constant & $\begin{array}{c}0.0857 \\
(2.2230)\end{array}$ & $\begin{array}{c}2.8819 \\
(2.8199) \\
\end{array}$ & $\begin{array}{c}-10.9182^{* *} \\
(4.4504)\end{array}$ & $\begin{array}{c}-13.8002^{* *} \\
(5.5981)\end{array}$ \\
\hline $\begin{array}{c}N \\
\text { Pseudo } \mathrm{R}^{2}\end{array}$ & $\begin{array}{c}916 \\
0.1382\end{array}$ & & $\begin{array}{c}916 \\
0.1893\end{array}$ & \\
\hline
\end{tabular}

Note: results report country-clustered standard errors. The model also includes cubic polynomials of a time trend variable to model temporal dependence as proposed by Carter and Signorino (2010).

${ }^{*} p<0.10 ;{ }^{* *} p<0.05 ; * * * p<0.01$. 
Table 4

\begin{tabular}{|c|c|c|c|c|}
\hline Model & (3) & \multicolumn{3}{|c|}{ (4) } \\
\hline $\begin{array}{c}\text { Comparison Group } \\
\text { vs. } \\
\text { Reference Group }\end{array}$ & $\begin{array}{c}\text { Breakdown } \\
\text { vs. } \\
\text { Survival } \\
\end{array}$ & $\begin{array}{c}\text { Replacement } \\
\text { vs. } \\
\text { Survival } \\
\end{array}$ & $\begin{array}{c}\text { Democracy } \\
\text { vs. } \\
\text { Survival } \\
\end{array}$ & $\begin{array}{l}\text { Democracy } \\
\text { vs. } \\
\text { Replacement }\end{array}$ \\
\hline RPSC & $\begin{array}{c}0.0089 \\
(0.0101)\end{array}$ & $\begin{array}{c}0.0126 \\
(0.0113)\end{array}$ & $\begin{array}{l}-0.0072 \\
(0.0211)\end{array}$ & $\begin{array}{l}-0.0198 \\
(0.0225)\end{array}$ \\
\hline$O P V-A$ & $\begin{array}{c}0.0170 \\
(0.0151)\end{array}$ & $\begin{array}{c}0.0044 \\
(0.0140)\end{array}$ & $\begin{array}{l}0.0623^{*} \\
(0.0362)\end{array}$ & $\begin{array}{c}0.0579 \\
(0.0368)\end{array}$ \\
\hline$O P V-B$ & $\begin{array}{c}0.0327 \\
(0.0318)\end{array}$ & $\begin{array}{l}-0.0281 \\
(0.0411)\end{array}$ & $\begin{array}{c}0.1619 * * * \\
(0.0484)\end{array}$ & $\begin{array}{c}0.1900^{* * *} \\
(0.0620)\end{array}$ \\
\hline Regime Age & $\begin{array}{c}-0.2667^{*} \\
(0.1459)\end{array}$ & $\begin{array}{c}-0.5102^{* * *} \\
(0.1663)\end{array}$ & $\begin{array}{c}0.3378 \\
(0.2636)\end{array}$ & $\begin{array}{c}0.8480^{* * *} \\
(0.3288)\end{array}$ \\
\hline Years Since Election & $\begin{array}{c}0.1296 \\
(0.1001)\end{array}$ & $\begin{array}{c}0.3323^{* * *} \\
(0.1203)\end{array}$ & $\begin{array}{l}-0.3450 \\
(0.2208)\end{array}$ & $\begin{array}{c}-0.6773^{* * *} \\
(0.2541)\end{array}$ \\
\hline ENP (ln) & $\begin{array}{c}0.3100 \\
(0.5391)\end{array}$ & $\begin{array}{c}0.8586 \\
(0.5884)\end{array}$ & $\begin{array}{l}-1.3366 \\
(1.0023)\end{array}$ & $\begin{array}{c}-2.1951^{* *} \\
(1.0019)\end{array}$ \\
\hline GDP per capita (ln) & $\begin{array}{c}-0.3428^{*} \\
(0.1860)\end{array}$ & $\begin{array}{c}-0.4326^{*} \\
(0.2316)\end{array}$ & $\begin{array}{l}-0.1812 \\
(0.3889)\end{array}$ & $\begin{array}{c}0.2515 \\
(0.4642)\end{array}$ \\
\hline GDP Growth & $\begin{array}{l}-2.8185 \\
(3.7092)\end{array}$ & $\begin{array}{l}-6.0007 \\
(3.9533)\end{array}$ & $\begin{array}{c}2.5155 \\
(6.7890)\end{array}$ & $\begin{array}{c}8.5163 \\
(7.1618)\end{array}$ \\
\hline Territory Control & $\begin{array}{l}-0.0130 \\
(0.0126)\end{array}$ & $\begin{array}{l}-0.0146 \\
(0.0149)\end{array}$ & $\begin{array}{c}0.0056 \\
(0.0228)\end{array}$ & $\begin{array}{c}0.0202 \\
(0.0266)\end{array}$ \\
\hline$E F$ & $\begin{array}{l}-0.8228 \\
(0.5421)\end{array}$ & $\begin{array}{c}-1.1424^{*} \\
(0.6164)\end{array}$ & $\begin{array}{c}0.0264 \\
(0.9110)\end{array}$ & $\begin{array}{c}1.1689 \\
(1.0421)\end{array}$ \\
\hline Election Accepted & $\begin{array}{c}0.3836^{* *} \\
(0.1591)\end{array}$ & $\begin{array}{c}0.2534 \\
(0.1618)\end{array}$ & $\begin{array}{c}1.0062^{* * *} \\
(0.3313)\end{array}$ & $\begin{array}{c}0.7528^{* *} \\
(0.3425)\end{array}$ \\
\hline Civil Society & $\begin{array}{c}1.8522^{* *} \\
(0.8218)\end{array}$ & $\begin{array}{c}0.9276 \\
(1.0219)\end{array}$ & $\begin{array}{c}4.6009 * * * \\
(1.5968)\end{array}$ & $\begin{array}{l}3.6733^{*} \\
(2.0002)\end{array}$ \\
\hline Regional Polyarchy & $\begin{array}{c}4.1415^{* * *} \\
(1.2295)\end{array}$ & $\begin{array}{c}2.2446 \\
(1.6840)\end{array}$ & $\begin{array}{c}7.8263^{* * *} \\
(2.0798)\end{array}$ & $\begin{array}{c}5.5817^{* *} \\
(2.6956)\end{array}$ \\
\hline Post-Cold War & $\begin{array}{c}-0.6808^{*} \\
(0.3571)\end{array}$ & $\begin{array}{l}-0.6939 \\
(0.4368)\end{array}$ & $\begin{array}{l}-0.7284 \\
(0.7321)\end{array}$ & $\begin{array}{l}-0.0345 \\
(0.8956)\end{array}$ \\
\hline Constant & $\begin{array}{c}0.2878 \\
(2.2523)\end{array}$ & $\begin{array}{c}2.5116 \\
(2.8162)\end{array}$ & $\begin{array}{c}-9.2492 * \\
(4.7195)\end{array}$ & $\begin{array}{c}-11.7608^{* *} \\
(5.8537)\end{array}$ \\
\hline $\begin{array}{c}N \\
\text { Pseudo } \mathrm{R}^{2}\end{array}$ & $\begin{array}{c}916 \\
0.1387\end{array}$ & & $\begin{array}{c}916 \\
0.1964\end{array}$ & \\
\hline
\end{tabular}

Note: results report country-clustered standard errors. The model also includes cubic polynomials of a time trend variable to model temporal dependence as proposed by Carter and Signorino (2010).

${ }^{*} p<0.10$; ** $p<0.05$; *** $p<0.01$. 
Table 5

\begin{tabular}{|c|c|c|c|c|}
\hline Model & (5) & & (6) & \\
\hline $\begin{array}{c}\text { Comparison Group } \\
\text { vs. } \\
\text { Reference Group }\end{array}$ & $\begin{array}{c}\text { Breakdown } \\
\text { vs. } \\
\text { Survival } \\
\end{array}$ & $\begin{array}{c}\text { Replacement } \\
\text { vs. } \\
\text { Survival } \\
\end{array}$ & $\begin{array}{c}\text { Democracy } \\
\text { vs. } \\
\text { Survival } \\
\end{array}$ & $\begin{array}{l}\text { Democracy } \\
\text { vs. } \\
\text { Replacement }\end{array}$ \\
\hline RPSC & $\begin{array}{l}0.0236^{*} \\
(0.0125)\end{array}$ & $\begin{array}{c}0.0138 \\
(0.0122)\end{array}$ & $\begin{array}{c}0.0350 \\
(0.0287)\end{array}$ & $\begin{array}{c}0.0212 \\
(0.0303)\end{array}$ \\
\hline$O P V-A$ & $\begin{array}{c}0.0174 \\
(0.0152)\end{array}$ & $\begin{array}{c}0.0043 \\
(0.0140)\end{array}$ & $\begin{array}{l}0.0726^{*} \\
(0.0373)\end{array}$ & $\begin{array}{l}0.0683^{*} \\
(0.0377)\end{array}$ \\
\hline$O P V-B$ & $\begin{array}{c}0.0461 \\
(0.0341)\end{array}$ & $\begin{array}{l}-0.0259 \\
(0.0437)\end{array}$ & $\begin{array}{c}0.2070^{* * *} \\
(0.0647)\end{array}$ & $\begin{array}{c}0.2329 * * * \\
(0.0771)\end{array}$ \\
\hline$R P S C \times O P V-B$ & $\begin{array}{c}-0.0029 * * \\
(0.0011)\end{array}$ & $\begin{array}{l}-0.0002 \\
(0.0016)\end{array}$ & $\begin{array}{c}-0.0076^{* * *} \\
(0.0025)\end{array}$ & $\begin{array}{c}-0.0073 * * \\
(0.0032)\end{array}$ \\
\hline Regime Age & $\begin{array}{c}-0.3125^{* *} \\
(0.1486)\end{array}$ & $\begin{array}{c}-0.5121 * * * \\
(0.1713)\end{array}$ & $\begin{array}{c}0.1904 \\
(0.2340)\end{array}$ & $\begin{array}{c}0.7025^{* *} \\
(0.2992)\end{array}$ \\
\hline Years Since Election & $\begin{array}{c}0.1291 \\
(0.1010)\end{array}$ & $\begin{array}{c}0.3317^{* * *} \\
(0.1202)\end{array}$ & $\begin{array}{l}-0.3256 \\
(0.2216)\end{array}$ & $\begin{array}{c}-0.6573 * * * \\
(0.2513)\end{array}$ \\
\hline ENP (ln) & $\begin{array}{c}0.1689 \\
(0.5411)\end{array}$ & $\begin{array}{c}0.8471 \\
(0.5864)\end{array}$ & $\begin{array}{c}-2.3000 * * \\
(1.0994)\end{array}$ & $\begin{array}{c}-3.1471 * * * \\
(1.0785)\end{array}$ \\
\hline GDP per capita (ln) & $\begin{array}{c}-0.3344^{*} \\
(0.1758)\end{array}$ & $\begin{array}{c}-0.4320^{*} \\
(0.2309)\end{array}$ & $\begin{array}{l}-0.1947 \\
(0.3165)\end{array}$ & $\begin{array}{c}0.2372 \\
(0.4014)\end{array}$ \\
\hline GDP Growth & $\begin{array}{l}-3.5123 \\
(3.8529)\end{array}$ & $\begin{array}{l}-6.0691 \\
(3.9928)\end{array}$ & $\begin{array}{c}0.2063 \\
(6.3355)\end{array}$ & $\begin{array}{c}6.2754 \\
(6.8194)\end{array}$ \\
\hline Territory Control & $\begin{array}{l}-0.0156 \\
(0.0128)\end{array}$ & $\begin{array}{l}-0.0145 \\
(0.0149)\end{array}$ & $\begin{array}{l}-0.0097 \\
(0.0219)\end{array}$ & $\begin{array}{c}0.0049 \\
(0.0257)\end{array}$ \\
\hline$E F$ & $\begin{array}{l}-0.7726 \\
(0.5589)\end{array}$ & $\begin{array}{c}-1.1320^{*} \\
(0.6229)\end{array}$ & $\begin{array}{c}0.0238 \\
(0.9044)\end{array}$ & $\begin{array}{c}1.1558 \\
(1.0121)\end{array}$ \\
\hline Election Accepted & $\begin{array}{c}0.3746^{* *} \\
(0.1551)\end{array}$ & $\begin{array}{c}0.2500 \\
(0.1605)\end{array}$ & $\begin{array}{c}1.0367 * * * \\
(0.2888)\end{array}$ & $\begin{array}{c}0.7867^{* *} \\
(0.3110)\end{array}$ \\
\hline Civil Society & $\begin{array}{c}1.7966^{* *} \\
(0.8368)\end{array}$ & $\begin{array}{c}0.9272 \\
(1.0236)\end{array}$ & $\begin{array}{c}4.7869 * * * \\
(1.6338)\end{array}$ & $\begin{array}{l}3.8597 * \\
(1.9747)\end{array}$ \\
\hline Regional Polyarchy & $\begin{array}{c}4.1137 * * * \\
(1.2470)\end{array}$ & $\begin{array}{c}2.2330 \\
(1.6904)\end{array}$ & $\begin{array}{c}8.5998^{* * *} \\
(2.1318)\end{array}$ & $\begin{array}{c}6.3668^{* *} \\
(2.6825)\end{array}$ \\
\hline Post-Cold War & $\begin{array}{c}-0.6531 * \\
(0.3537)\end{array}$ & $\begin{array}{l}-0.6980 \\
(0.4362)\end{array}$ & $\begin{array}{l}-0.7970 \\
(0.6434)\end{array}$ & $\begin{array}{l}-0.0990 \\
(0.8191)\end{array}$ \\
\hline Constant & $\begin{array}{c}0.6005 \\
(2.1860) \\
\end{array}$ & $\begin{array}{c}2.5048 \\
(2.8121) \\
\end{array}$ & $\begin{array}{l}-7.3442 * \\
(4.1424) \\
\end{array}$ & $\begin{array}{l}-9.8489 * \\
(5.3458)\end{array}$ \\
\hline $\begin{array}{c}N \\
\text { Pseudo } \mathrm{R}^{2}\end{array}$ & $\begin{array}{c}916 \\
0.1458\end{array}$ & & $\begin{array}{c}916 \\
0.2106\end{array}$ & \\
\hline
\end{tabular}

Note: results report country-clustered standard errors. The model also includes cubic polynomials of a time trend variable to model temporal dependence as proposed by Carter and Signorino (2010).

${ }^{*} p<0.10$; ${ }^{* *} p<0.05 ;{ }^{* * *} p<0.01$. 


\section{Appendix B: Re-estimating Table 5 including oil production per capita as a control variable}

Table B1

\begin{tabular}{|c|c|c|c|c|}
\hline Model & (7) & & (8) & \\
\hline $\begin{array}{c}\text { Comparison Group } \\
\text { vs. } \\
\text { Reference Group }\end{array}$ & $\begin{array}{l}\text { Breakdown } \\
\text { vs. } \\
\text { Survival }\end{array}$ & $\begin{array}{l}\text { Replacement } \\
\text { vs. } \\
\text { Survival }\end{array}$ & $\begin{array}{l}\text { Democracy } \\
\text { vs. } \\
\text { Survival }\end{array}$ & $\begin{array}{c}\text { Democracy } \\
\text { vs. } \\
\text { Replacement }\end{array}$ \\
\hline RPSC & $\begin{array}{c}0.0215 \\
(0.0142)\end{array}$ & $\begin{array}{c}0.0153 \\
(0.0148)\end{array}$ & $\begin{array}{c}0.0185 \\
(0.0314)\end{array}$ & $\begin{array}{c}0.0033 \\
(0.0333)\end{array}$ \\
\hline$O P V-A$ & $\begin{array}{c}0.0301 * * \\
(0.0145)\end{array}$ & $\begin{array}{c}0.0182 \\
(0.0131)\end{array}$ & $\begin{array}{l}0.0971 * \\
(0.0531)\end{array}$ & $\begin{array}{c}0.0789 \\
(0.0548)\end{array}$ \\
\hline$O P V-B$ & $\begin{array}{l}0.0641 * \\
(0.0331)\end{array}$ & $\begin{array}{l}-0.0016 \\
(0.0448)\end{array}$ & $\begin{array}{c}0.2444^{* * *} \\
(0.0868)\end{array}$ & $\begin{array}{c}0.2460 * * \\
(0.1005)\end{array}$ \\
\hline$R P S C \times O P V-B$ & $\begin{array}{c}-0.0033^{* * *} \\
(0.0012)\end{array}$ & $\begin{array}{l}-0.0013 \\
(0.0017)\end{array}$ & $\begin{array}{c}-0.0074 * * * \\
(0.0027)\end{array}$ & $\begin{array}{l}-0.0061 * \\
(0.0033)\end{array}$ \\
\hline Regime Age & $\begin{array}{c}-0.2926^{*} \\
(0.1606)\end{array}$ & $\begin{array}{c}-0.5092^{* * *} \\
(0.1878)\end{array}$ & $\begin{array}{c}0.2564 \\
(0.3320)\end{array}$ & $\begin{array}{l}0.7655^{*} \\
(0.4102)\end{array}$ \\
\hline Years Since Election & $\begin{array}{c}0.1856 \\
(0.1144)\end{array}$ & $\begin{array}{c}0.3913^{* * *} \\
(0.1328)\end{array}$ & $\begin{array}{l}-0.2400 \\
(0.2555)\end{array}$ & $\begin{array}{c}-0.6314^{* *} \\
(0.2890)\end{array}$ \\
\hline ENP $(m)$ & $\begin{array}{c}0.1269 \\
(0.6361)\end{array}$ & $\begin{array}{c}0.7609 \\
(0.6774)\end{array}$ & $\begin{array}{l}-3.0486^{*} \\
(1.8530)\end{array}$ & $\begin{array}{c}-3.8095^{* *} \\
(1.8383)\end{array}$ \\
\hline GDP per capita (In) & $\begin{array}{l}-0.0945 \\
(0.2792)\end{array}$ & $\begin{array}{l}-0.2386 \\
(0.3239)\end{array}$ & $\begin{array}{c}0.0786 \\
(0.5799)\end{array}$ & $\begin{array}{c}0.3172 \\
(0.6419)\end{array}$ \\
\hline GDP Growth & $\begin{array}{l}-5.5080 \\
(4.0468)\end{array}$ & $\begin{array}{c}-8.4627 * * \\
(4.1747)\end{array}$ & $\begin{array}{l}-0.2005 \\
(6.8638)\end{array}$ & $\begin{array}{c}8.2623 \\
(7.1084)\end{array}$ \\
\hline Territory Control & $\begin{array}{c}-0.0344 * * \\
(0.0147)\end{array}$ & $\begin{array}{c}-0.0335^{* *} \\
(0.0167)\end{array}$ & $\begin{array}{l}-0.0371 \\
(0.0285)\end{array}$ & $\begin{array}{l}-0.0036 \\
(0.0312)\end{array}$ \\
\hline$E F$ & $\begin{array}{l}-0.7378 \\
(0.5809)\end{array}$ & $\begin{array}{c}-1.0992^{*} \\
(0.6274)\end{array}$ & $\begin{array}{c}0.3450 \\
(0.9482)\end{array}$ & $\begin{array}{c}1.4441 \\
(1.0025)\end{array}$ \\
\hline Election Accepted & $\begin{array}{c}0.3538^{* *} \\
(0.1782)\end{array}$ & $\begin{array}{c}0.2709 \\
(0.1860)\end{array}$ & $\begin{array}{c}1.0233^{* * *} \\
(0.3968)\end{array}$ & $\begin{array}{l}0.7524 * \\
(0.4234)\end{array}$ \\
\hline Civil Society & $\begin{array}{c}2.0141 \text { ** } \\
(0.9671)\end{array}$ & $\begin{array}{c}1.2409 \\
(1.2017)\end{array}$ & $\begin{array}{c}4.4039 * * \\
(1.8264)\end{array}$ & $\begin{array}{c}3.1630 \\
(2.1766)\end{array}$ \\
\hline Regional Polyarchy & $\begin{array}{c}2.9819 * * \\
(1.4001)\end{array}$ & $\begin{array}{c}0.7680 \\
(1.8910)\end{array}$ & $\begin{array}{c}8.4182^{* * *} \\
(2.6762)\end{array}$ & $\begin{array}{l}7.6502 * * \\
(3.1437)\end{array}$ \\
\hline Post-Cold War & $\begin{array}{l}-0.2613 \\
(0.3638)\end{array}$ & $\begin{array}{l}-0.3262 \\
(0.4660)\end{array}$ & $\begin{array}{l}-0.4382 \\
(0.7372)\end{array}$ & $\begin{array}{l}-0.1120 \\
(0.9334)\end{array}$ \\
\hline Oil per capita (ln) & $\begin{array}{c}-0.3853^{* *} \\
(0.1882)\end{array}$ & $\begin{array}{l}-0.3155 \\
(0.2354)\end{array}$ & $\begin{array}{l}-0.6421 \\
(0.4741)\end{array}$ & $\begin{array}{l}-0.3266 \\
(0.5233)\end{array}$ \\
\hline Constant & $\begin{array}{c}0.5424 \\
(2.8339)\end{array}$ & $\begin{array}{c}3.1104 \\
(3.4607)\end{array}$ & $\begin{array}{l}-7.0190 \\
(5.2999)\end{array}$ & $\begin{array}{l}-10.1294 \\
(6.2143)\end{array}$ \\
\hline $\begin{array}{c}N \\
\text { Pseudo } \mathrm{R}^{2}\end{array}$ & $\begin{array}{c}787 \\
0.1711\end{array}$ & & $\begin{array}{c}787 \\
0.2362\end{array}$ & \\
\hline
\end{tabular}

Note: results report country-clustered standard errors. The model also includes cubic polynomials of a time trend variable to model temporal dependence as proposed by Carter and Signorino (2010).

${ }^{*} p<0.10 ; * * p<0.05 ; * * * p<0.01$. 
Appendix C: Re-estimating Table 5 including change in district magnitude as a control variable

Table C1

\begin{tabular}{|c|c|c|c|c|}
\hline Model & (9) & \multicolumn{3}{|c|}{ (10) } \\
\hline $\begin{array}{c}\text { Comparison Group } \\
\text { vs. } \\
\text { Reference Group }\end{array}$ & $\begin{array}{c}\text { Breakdown } \\
\text { vs. } \\
\text { Survival }\end{array}$ & $\begin{array}{l}\text { Replacement } \\
\text { vs. } \\
\text { Survival }\end{array}$ & $\begin{array}{c}\text { Democracy } \\
\text { vs. } \\
\text { Survival }\end{array}$ & $\begin{array}{c}\text { Democracy } \\
\text { vs. } \\
\text { Replacement }\end{array}$ \\
\hline RPSC & $\begin{array}{c}0.0159 \\
(0.0158)\end{array}$ & $\begin{array}{c}0.0125 \\
(0.0170)\end{array}$ & $\begin{array}{c}0.0249 \\
(0.0311)\end{array}$ & $\begin{array}{c}0.0124 \\
(0.0337)\end{array}$ \\
\hline$O P V-A$ & $\begin{array}{c}0.0215 \\
(0.0243)\end{array}$ & $\begin{array}{c}0.0207 \\
(0.0305)\end{array}$ & $\begin{array}{c}0.0097 \\
(0.0594)\end{array}$ & $\begin{array}{l}-0.0110 \\
(0.0671)\end{array}$ \\
\hline$O P V-B$ & $\begin{array}{c}0.0506 \\
(0.0685)\end{array}$ & $\begin{array}{l}-0.1025 \\
(0.0934)\end{array}$ & $\begin{array}{c}0.1686 * * \\
(0.0809)\end{array}$ & $\begin{array}{c}0.2711 * * \\
(0.1235)\end{array}$ \\
\hline$R P S C \times O P V-B$ & $\begin{array}{l}-0.0022 \\
(0.0016)\end{array}$ & $\begin{array}{c}0.0029 \\
(0.0027)\end{array}$ & $\begin{array}{c}-0.0079 * * \\
(0.0034)\end{array}$ & $\begin{array}{c}-0.0108^{* *} \\
(0.0045)\end{array}$ \\
\hline Regime Age & $\begin{array}{l}-0.1393 \\
(0.2371)\end{array}$ & $\begin{array}{l}-0.1715 \\
(0.3749)\end{array}$ & $\begin{array}{l}-0.0363 \\
(0.3390)\end{array}$ & $\begin{array}{c}0.1352 \\
(0.5237)\end{array}$ \\
\hline Years Since Election & $\begin{array}{c}0.0488 \\
(0.1173)\end{array}$ & $\begin{array}{l}0.2497^{*} \\
(0.1451)\end{array}$ & $\begin{array}{l}-0.2319 \\
(0.2816)\end{array}$ & $\begin{array}{l}-0.4816 \\
(0.3129)\end{array}$ \\
\hline ENP $(m)$ & $\begin{array}{l}-0.0657 \\
(0.9243)\end{array}$ & $\begin{array}{c}0.9943 \\
(1.1355)\end{array}$ & $\begin{array}{l}-2.4684 \\
(1.7358)\end{array}$ & $\begin{array}{l}-3.4628^{*} \\
(2.0318)\end{array}$ \\
\hline GDP per capita (In) & $\begin{array}{l}-0.3519 \\
(0.2323)\end{array}$ & $\begin{array}{l}-0.3521 \\
(0.2886)\end{array}$ & $\begin{array}{l}-0.4970 \\
(0.5127)\end{array}$ & $\begin{array}{l}-0.1449 \\
(0.5674)\end{array}$ \\
\hline GDP Growth & $\begin{array}{l}-3.3946 \\
(4.7562)\end{array}$ & $\begin{array}{l}-3.3507 \\
(5.4976)\end{array}$ & $\begin{array}{l}-10.2873 \\
(9.8266)\end{array}$ & $\begin{array}{c}-6.9366 \\
(10.5461)\end{array}$ \\
\hline Territory Control & $\begin{array}{l}-0.0351 \\
(0.0281)\end{array}$ & $\begin{array}{l}-0.0191 \\
(0.0395)\end{array}$ & $\begin{array}{l}-0.0538 \\
(0.0473)\end{array}$ & $\begin{array}{l}-0.0347 \\
(0.0639)\end{array}$ \\
\hline$E F$ & $\begin{array}{l}-0.5208 \\
(0.7556)\end{array}$ & $\begin{array}{l}-0.7894 \\
(0.8940)\end{array}$ & $\begin{array}{c}0.1595 \\
(1.5645)\end{array}$ & $\begin{array}{c}0.9489 \\
(1.7756)\end{array}$ \\
\hline Election Accepted & $\begin{array}{c}0.1794 \\
(0.2313)\end{array}$ & $\begin{array}{c}0.1175 \\
(0.2974)\end{array}$ & $\begin{array}{c}0.8140^{* * *} \\
(0.3005)\end{array}$ & $\begin{array}{l}0.6964^{*} \\
(0.4155)\end{array}$ \\
\hline Civil Society & $\begin{array}{c}1.9275 \\
(1.2267)\end{array}$ & $\begin{array}{c}0.1249 \\
(1.4467)\end{array}$ & $\begin{array}{c}7.7986^{* * *} \\
(2.6762)\end{array}$ & $\begin{array}{l}7.6737^{* *} \\
(3.0577)\end{array}$ \\
\hline Regional Polyarchy & $\begin{array}{c}5.2808 * * * \\
(1.8927)\end{array}$ & $\begin{array}{l}3.1792 \\
(2.8632)\end{array}$ & $\begin{array}{c}12.3402^{* * *} \\
(4.5185)\end{array}$ & $\begin{array}{l}9.1610^{*} \\
(5.3939)\end{array}$ \\
\hline Post-Cold War & $\begin{array}{l}-0.7641 \\
(0.6639)\end{array}$ & $\begin{array}{l}-0.2537 \\
(1.0175)\end{array}$ & $\begin{array}{l}-1.9014 * \\
(1.0878)\end{array}$ & $\begin{array}{l}-1.6477 \\
(1.6103)\end{array}$ \\
\hline District Magnitude Change & $\begin{array}{l}-0.0053 \\
(0.0041)\end{array}$ & $\begin{array}{l}-0.0365 \\
(0.0426)\end{array}$ & $\begin{array}{c}0.0008 \\
(0.0051)\end{array}$ & $\begin{array}{c}0.0373 \\
(0.0432)\end{array}$ \\
\hline Constant & $\begin{array}{r}1.3446 \\
(3.5708) \\
\end{array}$ & $\begin{array}{c}0.2541 \\
(4.7087) \\
\end{array}$ & $\begin{array}{r}-0.9898 \\
(6.6832) \\
\end{array}$ & $\begin{array}{l}-1.2439 \\
(8.3054) \\
\end{array}$ \\
\hline $\begin{array}{c}N \\
\text { Pseudo R }\end{array}$ & $\begin{array}{c}620 \\
0.1379\end{array}$ & & $\begin{array}{c}620 \\
0.2350\end{array}$ & \\
\hline
\end{tabular}

Note: results report country-clustered standard errors. The model also includes cubic polynomials of a time trend variable to model temporal dependence as proposed by Carter and Signorino (2010).

${ }^{*} p<0.10 ; * * p<0.05 ; * * * p<0.01$. 


\section{Appendix D: Re-estimating Table 5 including ODA per capita as a control}

\section{variable}

Table D1

\begin{tabular}{|c|c|c|c|c|}
\hline Model & (11) & & (12) & \\
\hline $\begin{array}{c}\text { Comparison Group } \\
\text { vs. } \\
\text { Reference Group }\end{array}$ & $\begin{array}{c}\text { Breakdown } \\
\text { vs. } \\
\text { Survival } \\
\end{array}$ & $\begin{array}{c}\text { Replacement } \\
\text { vs. } \\
\text { Survival } \\
\end{array}$ & $\begin{array}{c}\text { Democracy } \\
\text { vs. } \\
\text { Survival } \\
\end{array}$ & $\begin{array}{l}\text { Democracy } \\
\text { vs. } \\
\text { Replacement }\end{array}$ \\
\hline RPSC & $\begin{array}{l}0.0212 * \\
(0.0129)\end{array}$ & $\begin{array}{c}0.0128 \\
(0.0134)\end{array}$ & $\begin{array}{c}0.0337 \\
(0.0291)\end{array}$ & $\begin{array}{c}0.0209 \\
(0.0316)\end{array}$ \\
\hline$O P V-A$ & $\begin{array}{c}0.0099 \\
(0.0169)\end{array}$ & $\begin{array}{l}-0.0074 \\
(0.0168)\end{array}$ & $\begin{array}{c}0.0670 \\
(0.0456)\end{array}$ & $\begin{array}{c}0.0745 \\
(0.0484)\end{array}$ \\
\hline$O P V-B$ & $\begin{array}{c}0.0448 \\
(0.0433)\end{array}$ & $\begin{array}{l}-0.0297 \\
(0.0512)\end{array}$ & $\begin{array}{c}0.2017 * * \\
(0.0823)\end{array}$ & $\begin{array}{c}0.2314^{* *} \\
(0.0929)\end{array}$ \\
\hline$R P S C \times O P V-B$ & $\begin{array}{c}-0.0027^{* *} \\
(0.0012)\end{array}$ & $\begin{array}{c}0.0004 \\
(0.0016)\end{array}$ & $\begin{array}{c}-0.0081 * * * \\
(0.0026)\end{array}$ & $\begin{array}{c}-0.0085^{* * *} \\
(0.0033)\end{array}$ \\
\hline Regime Age & $\begin{array}{c}-0.3086 * * \\
(0.1555)\end{array}$ & $\begin{array}{c}-0.4531 * * \\
(0.1818)\end{array}$ & $\begin{array}{l}-0.0250 \\
(0.2140)\end{array}$ & $\begin{array}{c}0.4282 \\
(0.2728)\end{array}$ \\
\hline Years Since Election & $\begin{array}{c}0.0985 \\
(0.1089)\end{array}$ & $\begin{array}{c}0.3284 * * * \\
(0.1275)\end{array}$ & $\begin{array}{l}-0.3719 \\
(0.2564)\end{array}$ & $\begin{array}{c}-0.7004 * * \\
(0.2831)\end{array}$ \\
\hline$E N P(\ln )$ & $\begin{array}{l}-0.1767 \\
(0.6963)\end{array}$ & $\begin{array}{c}0.7647 \\
(0.8325)\end{array}$ & $\begin{array}{c}-2.9377^{*} \\
(1.5217)\end{array}$ & $\begin{array}{c}-3.7024 * * \\
(1.6323)\end{array}$ \\
\hline GDP per capita (ln) & $\begin{array}{l}-0.2547 \\
(0.1810)\end{array}$ & $\begin{array}{l}-0.3305 \\
(0.2460)\end{array}$ & $\begin{array}{l}-0.3113 \\
(0.3397)\end{array}$ & $\begin{array}{c}0.0191 \\
(0.4214)\end{array}$ \\
\hline GDP Growth & $\begin{array}{l}-4.9518 \\
(4.4268)\end{array}$ & $\begin{array}{l}-6.1905 \\
(4.7049)\end{array}$ & $\begin{array}{l}-3.5060 \\
(6.5528)\end{array}$ & $\begin{array}{c}2.6845 \\
(7.0860)\end{array}$ \\
\hline Territory Control & $\begin{array}{c}-0.0301 * \\
(0.0159)\end{array}$ & $\begin{array}{l}-0.0271 \\
(0.0210)\end{array}$ & $\begin{array}{l}-0.0267 \\
(0.0276)\end{array}$ & $\begin{array}{c}0.0004 \\
(0.0357)\end{array}$ \\
\hline$E F$ & $\begin{array}{l}-0.7538 \\
(0.6191)\end{array}$ & $\begin{array}{l}-1.0462 \\
(0.7756)\end{array}$ & $\begin{array}{l}-0.0350 \\
(1.1122)\end{array}$ & $\begin{array}{c}1.0112 \\
(1.3629)\end{array}$ \\
\hline Election Accepted & $\begin{array}{c}0.3175^{* *} \\
(0.1617)\end{array}$ & $\begin{array}{c}0.1503 \\
(0.1734)\end{array}$ & $\begin{array}{c}0.9896^{* * *} \\
(0.3728)\end{array}$ & $\begin{array}{c}0.8394 * * \\
(0.4038)\end{array}$ \\
\hline Civil Society & $\begin{array}{c}2.4658^{* *} \\
(0.9856)\end{array}$ & $\begin{array}{c}1.5107 \\
(1.2156)\end{array}$ & $\begin{array}{c}5.8054 * * * \\
(2.2274)\end{array}$ & $\begin{array}{l}4.2947 * \\
(2.5780)\end{array}$ \\
\hline Regional Polyarchy & $\begin{array}{c}4.2219 * * * \\
(1.3148)\end{array}$ & $\begin{array}{c}2.7864 \\
(1.8249)\end{array}$ & $\begin{array}{c}8.3824 * * * \\
(2.5323)\end{array}$ & $\begin{array}{l}5.5961 * \\
(3.1989)\end{array}$ \\
\hline Post-Cold War & $\begin{array}{l}-0.5254 \\
(0.3902)\end{array}$ & $\begin{array}{l}-0.7086 \\
(0.5159)\end{array}$ & $\begin{array}{l}-0.4402 \\
(0.6908)\end{array}$ & $\begin{array}{c}0.2684 \\
(0.9131)\end{array}$ \\
\hline ODA per capita (ln) & $\begin{array}{c}0.0285 \\
(0.1522)\end{array}$ & $\begin{array}{c}0.0204 \\
(0.1848)\end{array}$ & $\begin{array}{c}0.0372 \\
(0.2617)\end{array}$ & $\begin{array}{c}0.0168 \\
(0.2980)\end{array}$ \\
\hline Constant & $\begin{array}{c}1.6073 \\
(2.5976) \\
\end{array}$ & $\begin{array}{c}3.0609 \\
(3.5692) \\
\end{array}$ & $\begin{array}{l}-3.7822 \\
(4.7850) \\
\end{array}$ & $\begin{array}{l}-6.8431 \\
(6.3102) \\
\end{array}$ \\
\hline $\begin{array}{c}N \\
\text { Pseudo } \mathrm{R}^{2}\end{array}$ & $\begin{array}{c}808 \\
0.1489\end{array}$ & & $\begin{array}{c}808 \\
0.2174\end{array}$ & \\
\hline
\end{tabular}

Note: results report country-clustered standard errors. The model also includes cubic polynomials of a time trend variable to model temporal dependence as proposed by Carter and Signorino (2010).

${ }^{*} p<0.10 ; * * p<0.05 ; * * * p<0.01$. 
Appendix E: Re-estimating Table 5 without using linear prediction and supplementing missing countries with Alesina et al. (2003) for ethnic

\section{fractionalization scores}

\section{Table E1}

\begin{tabular}{|c|c|c|c|c|}
\hline Model & (13) & & (14) & \\
\hline $\begin{array}{c}\text { Comparison Group } \\
\text { vs. } \\
\text { Reference Group }\end{array}$ & $\begin{array}{c}\text { Breakdown } \\
\text { vs. } \\
\text { Survival }\end{array}$ & $\begin{array}{c}\text { Replacement } \\
\text { vs. } \\
\text { Survival }\end{array}$ & $\begin{array}{c}\text { Democracy } \\
\text { vs. } \\
\text { Survival }\end{array}$ & $\begin{array}{c}\text { Democracy } \\
\text { vs. } \\
\text { Replacement }\end{array}$ \\
\hline RPSC & $\begin{array}{c}0.0147 \\
(0.0133)\end{array}$ & $\begin{array}{c}0.0116 \\
(0.0135)\end{array}$ & $\begin{array}{l}-0.0015 \\
(0.0332)\end{array}$ & $\begin{array}{l}-0.0131 \\
(0.0345)\end{array}$ \\
\hline$O P V-A$ & $\begin{array}{c}0.0304^{* *} \\
(0.0150)\end{array}$ & $\begin{array}{c}0.0161 \\
(0.0137)\end{array}$ & $\begin{array}{c}0.1331^{* *} \\
(0.0600)\end{array}$ & $\begin{array}{l}0.1171 * \\
(0.0605)\end{array}$ \\
\hline$O P V-B$ & $\begin{array}{c}0.0711^{* *} \\
(0.0341)\end{array}$ & $\begin{array}{c}0.0056 \\
(0.0443)\end{array}$ & $\begin{array}{c}0.2948^{* * *} \\
(0.1121)\end{array}$ & $\begin{array}{c}0.2892^{* *} \\
(0.1198)\end{array}$ \\
\hline$R P S C \times O P V-B$ & $\begin{array}{c}-0.0031 * * \\
(0.0012)\end{array}$ & $\begin{array}{l}-0.0012 \\
(0.0017)\end{array}$ & $\begin{array}{c}-0.0090 * * \\
(0.0036)\end{array}$ & $\begin{array}{c}-0.0079 * * \\
(0.0039)\end{array}$ \\
\hline Regime Age & $\begin{array}{c}-0.2646^{*} \\
(0.1537)\end{array}$ & $\begin{array}{c}-0.4710^{* * *} \\
(0.1793)\end{array}$ & $\begin{array}{c}0.3267 \\
(0.3934)\end{array}$ & $\begin{array}{l}0.7977 * \\
(0.4664)\end{array}$ \\
\hline Years Since Election & $\begin{array}{c}0.2594 * * \\
(0.1112)\end{array}$ & $\begin{array}{c}0.4051 * * * \\
(0.1322)\end{array}$ & $\begin{array}{c}0.0416 \\
(0.2518)\end{array}$ & $\begin{array}{l}-0.3636 \\
(0.2886)\end{array}$ \\
\hline ENP $(\ln )$ & $\begin{array}{l}-0.0826 \\
(0.6421)\end{array}$ & $\begin{array}{c}0.6095 \\
(0.6579)\end{array}$ & $\begin{array}{c}-4.5277^{*} \\
(2.3957)\end{array}$ & $\begin{array}{c}-5.1372^{* *} \\
(2.3092)\end{array}$ \\
\hline GDP per capita (ln) & $\begin{array}{l}-0.1413 \\
(0.2250)\end{array}$ & $\begin{array}{l}-0.3508 \\
(0.2749)\end{array}$ & $\begin{array}{c}0.3736 \\
(0.5507)\end{array}$ & $\begin{array}{c}0.7244 \\
(0.5986)\end{array}$ \\
\hline GDP Growth & $\begin{array}{l}-5.6747 \\
(4.0514)\end{array}$ & $\begin{array}{c}-8.6829 * * \\
(4.0902)\end{array}$ & $\begin{array}{c}0.0947 \\
(7.7018)\end{array}$ & $\begin{array}{c}8.7776 \\
(7.8685)\end{array}$ \\
\hline Territory Control & $\begin{array}{c}-0.0259 * \\
(0.0144)\end{array}$ & $\begin{array}{l}-0.0254 \\
(0.0158)\end{array}$ & $\begin{array}{l}-0.0241 \\
(0.0304)\end{array}$ & $\begin{array}{c}0.0013 \\
(0.0330)\end{array}$ \\
\hline$E F$ & $\begin{array}{l}-0.9222 \\
(0.5833)\end{array}$ & $\begin{array}{l}-1.1158^{*} \\
(0.6217)\end{array}$ & $\begin{array}{c}0.5884 \\
(1.0640)\end{array}$ & $\begin{array}{c}1.7041 \\
(1.1290)\end{array}$ \\
\hline Election Accepted & $\begin{array}{l}0.3750^{* *} \\
(0.1699)\end{array}$ & $\begin{array}{l}0.2890^{*} \\
(0.1753)\end{array}$ & $\begin{array}{l}1.2645^{* *} \\
(0.4971)\end{array}$ & $\begin{array}{l}0.9755^{*} \\
(0.5151)\end{array}$ \\
\hline Civil Society & $\begin{array}{c}2.0978^{* *} \\
(0.9305)\end{array}$ & $\begin{array}{c}1.1985 \\
(1.1593)\end{array}$ & $\begin{array}{l}5.9914 * * \\
(2.7990)\end{array}$ & $\begin{array}{c}4.7930 \\
(3.1091)\end{array}$ \\
\hline Regional Polyarchy & $\begin{array}{c}3.7898^{* * * *} \\
(1.3344)\end{array}$ & $\begin{array}{c}1.3981 \\
(1.7372)\end{array}$ & $\begin{array}{c}12.0548^{* * *} \\
(2.6245)\end{array}$ & $\begin{array}{c}10.6567 * * * \\
(2.9506)\end{array}$ \\
\hline Post-Cold War & $\begin{array}{l}-0.4815 \\
(0.3559)\end{array}$ & $\begin{array}{l}-0.4644 \\
(0.4372)\end{array}$ & $\begin{array}{c}-1.3972 * * \\
(0.6668)\end{array}$ & $\begin{array}{l}-0.9328 \\
(0.8649)\end{array}$ \\
\hline Constant & $\begin{array}{c}0.0471 \\
(2.5116) \\
\end{array}$ & $\begin{array}{c}3.1283 \\
(3.1736) \\
\end{array}$ & $\begin{array}{c}-12.2981 * * \\
(5.7162) \\
\end{array}$ & $\begin{array}{c}-15.4264 * * \\
(6.5835) \\
\end{array}$ \\
\hline $\begin{array}{c}N \\
\text { Pseudo } \mathrm{R}^{2}\end{array}$ & $\begin{array}{c}726 \\
0.1597\end{array}$ & & $\begin{array}{c}726 \\
0.2355\end{array}$ & \\
\hline
\end{tabular}

Note: results report country-clustered standard errors. The model also includes cubic polynomials of a time trend variable to model temporal dependence as proposed by Carter and Signorino (2010).

${ }^{*} p<0.10$; ** $p<0.05$; *** $p<0.01$. 


\section{Appendix F: Re-estimating Table 5 excluding censored observations}

Table F1

\begin{tabular}{|c|c|c|c|c|}
\hline Model & (15) & & (16) & \\
\hline $\begin{array}{c}\text { Comparison Group } \\
\text { vs. } \\
\text { Reference Group }\end{array}$ & $\begin{array}{c}\text { Breakdown } \\
\text { vs. } \\
\text { Survival }\end{array}$ & $\begin{array}{c}\text { Replacement } \\
\text { vs. } \\
\text { Survival }\end{array}$ & $\begin{array}{c}\text { Democracy } \\
\text { vs. } \\
\text { Survival }\end{array}$ & $\begin{array}{l}\text { Democracy } \\
\text { vs. } \\
\text { Replacement }\end{array}$ \\
\hline RPSC & $\begin{array}{l}0.0248^{*} \\
(0.0143)\end{array}$ & $\begin{array}{c}0.0157 \\
(0.0149)\end{array}$ & $\begin{array}{c}0.0308 \\
(0.0319)\end{array}$ & $\begin{array}{c}0.0151 \\
(0.0325)\end{array}$ \\
\hline$O P V-A$ & $\begin{array}{c}0.0392 * * * \\
(0.0148)\end{array}$ & $\begin{array}{l}0.0240 * \\
(0.0144)\end{array}$ & $\begin{array}{l}0.1071 * * \\
(0.0452)\end{array}$ & $\begin{array}{l}0.0832 * \\
(0.0479)\end{array}$ \\
\hline$O P V-B$ & $\begin{array}{c}0.0358 \\
(0.0329)\end{array}$ & $\begin{array}{l}-0.0289 \\
(0.0440)\end{array}$ & $\begin{array}{c}0.1972^{* * *} \\
(0.0734)\end{array}$ & $\begin{array}{c}0.2262^{* *} \\
(0.0883)\end{array}$ \\
\hline$R P S C \times O P V-B$ & $\begin{array}{c}-0.0030^{* *} \\
(0.0012)\end{array}$ & $\begin{array}{l}-0.0009 \\
(0.0017)\end{array}$ & $\begin{array}{c}-0.0071 * * * \\
(0.0026)\end{array}$ & $\begin{array}{l}-0.0062 * \\
(0.0032)\end{array}$ \\
\hline Regime Age & $\begin{array}{l}-0.1403 \\
(0.1395)\end{array}$ & $\begin{array}{c}-0.3396^{*} \\
(0.1773)\end{array}$ & $\begin{array}{c}0.3381 \\
(0.2693)\end{array}$ & $\begin{array}{l}0.6777 * \\
(0.3491)\end{array}$ \\
\hline Years Since Election & $\begin{array}{c}0.1596 \\
(0.1145)\end{array}$ & $\begin{array}{c}0.3499 * * \\
(0.1368)\end{array}$ & $\begin{array}{l}-0.2839 \\
(0.2503)\end{array}$ & $\begin{array}{c}-0.6338^{* *} \\
(0.2770)\end{array}$ \\
\hline ENP (ln) & $\begin{array}{c}0.1580 \\
(0.5583)\end{array}$ & $\begin{array}{c}0.7888 \\
(0.6325)\end{array}$ & $\begin{array}{c}-2.4870^{*} \\
(1.3596)\end{array}$ & $\begin{array}{c}-3.2758^{* *} \\
(1.3421)\end{array}$ \\
\hline GDP per capita (ln) & $\begin{array}{l}-0.1151 \\
(0.2071)\end{array}$ & $\begin{array}{l}-0.2398 \\
(0.2836)\end{array}$ & $\begin{array}{c}0.0460 \\
(0.3500)\end{array}$ & $\begin{array}{c}0.2858 \\
(0.4450)\end{array}$ \\
\hline GDP Growth & $\begin{array}{l}-4.7493 \\
(4.0879)\end{array}$ & $\begin{array}{l}-6.9323 \\
(4.6018)\end{array}$ & $\begin{array}{l}-2.7045 \\
(6.0607)\end{array}$ & $\begin{array}{c}4.2277 \\
(6.8717)\end{array}$ \\
\hline Territory Control & $\begin{array}{l}-0.0183 \\
(0.0123)\end{array}$ & $\begin{array}{l}-0.0135 \\
(0.0141)\end{array}$ & $\begin{array}{l}-0.0217 \\
(0.0241)\end{array}$ & $\begin{array}{l}-0.0081 \\
(0.0279)\end{array}$ \\
\hline$E F$ & $\begin{array}{c}-0.9981 * \\
(0.5410)\end{array}$ & $\begin{array}{c}-1.1603 * * \\
(0.5894)\end{array}$ & $\begin{array}{l}-0.4520 \\
(0.9852)\end{array}$ & $\begin{array}{c}0.7083 \\
(1.0047)\end{array}$ \\
\hline Election Accepted & $\begin{array}{l}0.3588^{*} \\
(0.1910)\end{array}$ & $\begin{array}{c}0.2306 \\
(0.1909)\end{array}$ & $\begin{array}{c}1.0461^{* * *} \\
(0.3815)\end{array}$ & $\begin{array}{l}0.8156^{* *} \\
(0.3880)\end{array}$ \\
\hline Civil Society & $\begin{array}{c}2.0517 * * * \\
(0.7816)\end{array}$ & $\begin{array}{c}1.4325 \\
(1.0092)\end{array}$ & $\begin{array}{c}4.2923^{* * *} \\
(1.5904)\end{array}$ & $\begin{array}{c}2.8598 \\
(1.9668)\end{array}$ \\
\hline Regional Polyarchy & $\begin{array}{c}3.0256^{* *} \\
(1.1966)\end{array}$ & $\begin{array}{c}1.3708 \\
(1.5901)\end{array}$ & $\begin{array}{c}7.3132 * * * \\
(2.2403)\end{array}$ & $\begin{array}{c}5.9423^{* *} \\
(2.7080)\end{array}$ \\
\hline Post-Cold War & $\begin{array}{l}-0.0275 \\
(0.3238)\end{array}$ & $\begin{array}{l}-0.1642 \\
(0.3812)\end{array}$ & $\begin{array}{c}0.0593 \\
(0.6961)\end{array}$ & $\begin{array}{c}0.2235 \\
(0.8057)\end{array}$ \\
\hline Constant & $\begin{array}{l}-1.4640 \\
(2.2436)\end{array}$ & $\begin{array}{c}0.0863 \\
(3.0354)\end{array}$ & $\begin{array}{l}-7.9512^{*} \\
(4.3247)\end{array}$ & $\begin{array}{l}-8.0376 \\
(5.6959)\end{array}$ \\
\hline $\begin{array}{c}N \\
\text { Pseudo R }\end{array}$ & $\begin{array}{c}566 \\
0.1324\end{array}$ & & $\begin{array}{c}566 \\
0.1989\end{array}$ & \\
\hline
\end{tabular}

Note: results report country-clustered standard errors. The model also includes cubic polynomials of a time trend variable to model temporal dependence as proposed by Carter and Signorino (2010).

${ }^{*} p<0.10 ; * * x<0.05 ; * * * p<0.01$. 
Appendix G: Re-estimating Table 5 after including all variables and using MICE to impute missing observations

Table G1

\begin{tabular}{|c|c|c|c|c|}
\hline Model & (17) & & (18) & \\
\hline $\begin{array}{c}\text { Comparison Group } \\
\text { vs. } \\
\text { Reference Group }\end{array}$ & $\begin{array}{c}\text { Breakdown } \\
\text { vs. } \\
\text { Survival }\end{array}$ & $\begin{array}{c}\text { Replacement } \\
\text { vs. } \\
\text { Survival }\end{array}$ & $\begin{array}{c}\text { Democracy } \\
\text { vs. } \\
\text { Survival }\end{array}$ & $\begin{array}{l}\text { Democracy } \\
\text { vs. } \\
\text { Replacement }\end{array}$ \\
\hline RPSC & $\begin{array}{c}0.0251 * * \\
(0.0127)\end{array}$ & $\begin{array}{c}0.0140 \\
(0.0124)\end{array}$ & $\begin{array}{c}0.0362 \\
(0.0291)\end{array}$ & $\begin{array}{c}0.0222 \\
(0.0311)\end{array}$ \\
\hline$O P V-A$ & $\begin{array}{c}0.0166 \\
(0.0150)\end{array}$ & $\begin{array}{c}0.0082 \\
(0.0146)\end{array}$ & $\begin{array}{c}0.0574 \\
(0.0411)\end{array}$ & $\begin{array}{c}0.0492 \\
(0.0422)\end{array}$ \\
\hline$O P V-B$ & $\begin{array}{c}0.0299 \\
(0.0357)\end{array}$ & $\begin{array}{l}-0.0359 \\
(0.0447)\end{array}$ & $\begin{array}{c}0.1690 * * \\
(0.0759)\end{array}$ & $\begin{array}{c}0.2049 * * \\
(0.0851)\end{array}$ \\
\hline$R P S C \times O P V-B$ & $\begin{array}{c}-0.0029 * * \\
(0.0012)\end{array}$ & $\begin{array}{c}0.0000 \\
(0.0016)\end{array}$ & $\begin{array}{c}-0.0077 * * * \\
(0.0026)\end{array}$ & $\begin{array}{c}-0.0077 * * \\
(0.0034)\end{array}$ \\
\hline Regime Age & $\begin{array}{c}-0.2513 * \\
(0.1496)\end{array}$ & $\begin{array}{c}-0.4190 * * \\
(0.1827)\end{array}$ & $\begin{array}{c}0.2012 \\
(0.2485)\end{array}$ & $\begin{array}{c}0.6202^{* *} \\
(0.3134)\end{array}$ \\
\hline Years Since Election & $\begin{array}{c}0.1279 \\
(0.0963)\end{array}$ & $\begin{array}{c}0.3181 * * * \\
(0.1174)\end{array}$ & $\begin{array}{c}-0.3570^{*} \\
(0.2120)\end{array}$ & $\begin{array}{c}-0.6751^{* * *} \\
(0.2477)\end{array}$ \\
\hline ENP (ln) & $\begin{array}{c}0.3407 \\
(0.4995)\end{array}$ & $\begin{array}{l}1.0621^{*} \\
(0.5974)\end{array}$ & $\begin{array}{c}-2.0244^{*} \\
(1.0570)\end{array}$ & $\begin{array}{c}-3.0865^{* * *} \\
(1.1201)\end{array}$ \\
\hline GDP per capita (ln) & $\begin{array}{l}-0.2218 \\
(0.2670)\end{array}$ & $\begin{array}{l}-0.4189 \\
(0.3410)\end{array}$ & $\begin{array}{c}0.1255 \\
(0.5136)\end{array}$ & $\begin{array}{c}0.5444 \\
(0.6249)\end{array}$ \\
\hline GDP Growth & $\begin{array}{l}-3.4217 \\
(3.8723)\end{array}$ & $\begin{array}{l}-5.3056 \\
(4.1268)\end{array}$ & $\begin{array}{l}-0.3613 \\
(6.4658)\end{array}$ & $\begin{array}{c}4.9443 \\
(7.0547)\end{array}$ \\
\hline Territory Control & $\begin{array}{l}-0.0153 \\
(0.0138)\end{array}$ & $\begin{array}{l}-0.0153 \\
(0.0161)\end{array}$ & $\begin{array}{c}0.0002 \\
(0.0270)\end{array}$ & $\begin{array}{c}0.0154 \\
(0.0306)\end{array}$ \\
\hline EF & $\begin{array}{l}-0.4395 \\
(0.7004)\end{array}$ & $\begin{array}{l}-1.1546 \\
(0.7504)\end{array}$ & $\begin{array}{c}1.2205 \\
(1.5698)\end{array}$ & $\begin{array}{c}2.3752 \\
(1.6122)\end{array}$ \\
\hline Election Accepted & $\begin{array}{c}0.3630 * * \\
(0.1606)\end{array}$ & $\begin{array}{l}0.2902^{*} \\
(0.1719)\end{array}$ & $\begin{array}{c}0.8922 * * * \\
(0.2858)\end{array}$ & $\begin{array}{c}0.6021 * * \\
(0.3044)\end{array}$ \\
\hline Civil Society & $\begin{array}{c}1.6724^{* *} \\
(0.8342)\end{array}$ & $\begin{array}{c}1.1744 \\
(1.0637)\end{array}$ & $\begin{array}{c}3.6957 * * \\
(1.6296)\end{array}$ & $\begin{array}{c}2.5213 \\
(1.9598)\end{array}$ \\
\hline Regional Polyarchy & $\begin{array}{c}4.6935^{* * *} \\
(1.3076)\end{array}$ & $\begin{array}{l}2.9872^{*} \\
(1.7007)\end{array}$ & $\begin{array}{c}9.2690 * * * \\
(2.4104)\end{array}$ & $\begin{array}{c}6.2818^{* *} \\
(2.8565)\end{array}$ \\
\hline Post-Cold War & $\begin{array}{c}-0.6894 * * \\
(0.3335)\end{array}$ & $\begin{array}{c}-0.7858^{*} \\
(0.4237)\end{array}$ & $\begin{array}{l}-0.6994 \\
(0.6420)\end{array}$ & $\begin{array}{c}0.0864 \\
(0.8024)\end{array}$ \\
\hline Oil per capita (ln) & $\begin{array}{l}-0.0412 \\
(0.1192)\end{array}$ & $\begin{array}{c}0.0094 \\
(0.1455)\end{array}$ & $\begin{array}{l}-0.1708 \\
(0.1984)\end{array}$ & $\begin{array}{l}-0.1802 \\
(0.2151)\end{array}$ \\
\hline District Magnitude Change & $\begin{array}{l}-0.0083 \\
(0.0092)\end{array}$ & $\begin{array}{l}-0.0135 \\
(0.0131)\end{array}$ & $\begin{array}{l}-0.0001 \\
(0.0109)\end{array}$ & $\begin{array}{c}0.0133 \\
(0.0165)\end{array}$ \\
\hline ODA per capita (ln) & $\begin{array}{c}0.0239 \\
(0.1931)\end{array}$ & $\begin{array}{l}-0.0455 \\
(0.2424)\end{array}$ & $\begin{array}{c}0.1713 \\
(0.3525)\end{array}$ & $\begin{array}{c}0.2168 \\
(0.4120)\end{array}$ \\
\hline Constant & $\begin{array}{l}-0.6690 \\
(2.5454) \\
\end{array}$ & $\begin{array}{r}1.5302 \\
(3.3354) \\
\end{array}$ & $\begin{array}{c}-10.1632^{*} \\
(5.5673) \\
\end{array}$ & $\begin{array}{c}-11.6934^{*} \\
(6.8282) \\
\end{array}$ \\
\hline$N$ & 940 & & 940 & \\
\hline
\end{tabular}

Note: results report country-clustered standard errors. The model also includes cubic polynomials of a time trend variable to model temporal dependence as proposed by Carter and Signorino (2010).

${ }^{*} p<0.10 ; * * p<0.05$; *** $p<0.01$. 


\section{Appendix H: Re-estimating Table 5 dropping one country at a time}

Given that this procedure generates 79 sets of coefficient estimates, i.e., one iteration for each country in our sample, we present the coefficient estimates for RPSC, OPV-A, OPV-B, RPSC $\times$ $O P V-B$ when regime survival is the reference group and democratic transition is the comparison group.

Table H1

\begin{tabular}{|c|c|c|c|c|}
\hline Dropped Country & RPSC & $O P V-A$ & $O P V-B$ & $\begin{array}{l}\text { RPSC } \times \\
O P V-B\end{array}$ \\
\hline Albania & 0.038 & $0.0732 *$ & $0.207 * * *$ & $-0.00741^{* * *}$ \\
\hline Algeria & 0.035 & $0.0725^{*}$ & $0.206 * * *$ & $-0.00755^{* * *}$ \\
\hline Angola & 0.0349 & $0.0725^{*}$ & $0.207 * * *$ & $-0.00756 * * *$ \\
\hline Argentina & 0.0357 & $0.0719 * *$ & $0.211^{* * *}$ & $-0.00744 * * *$ \\
\hline Armenia & 0.0349 & $0.0725^{*}$ & $0.207 * * *$ & $-0.00753^{* * *}$ \\
\hline Azerbaijan & 0.035 & $0.0724 *$ & $0.207 * * *$ & $-0.00755^{* * *}$ \\
\hline Bangladesh & 0.0351 & $0.0712^{*}$ & $0.202^{* * *}$ & $-0.00752 * * *$ \\
\hline Belarus & 0.0348 & $0.0724^{*}$ & $0.207 * * *$ & $-0.00756^{* * *}$ \\
\hline Bolivia & 0.0344 & $0.0724 * *$ & $0.212^{* * *}$ & $-0.00760^{* * *}$ \\
\hline Brazil & 0.0351 & $0.0716^{*}$ & $0.204^{* * *}$ & $-0.00750^{* * *}$ \\
\hline Burkina Faso & 0.0326 & $0.0705^{*}$ & $0.209 * * *$ & $-0.00704 * * *$ \\
\hline Burma/Myanmar & 0.0346 & $0.0714^{*}$ & $0.206^{* * *}$ & $-0.00760 * * *$ \\
\hline Burundi & 0.0349 & $0.0718^{*}$ & $0.208^{* * *}$ & $-0.00746^{* * *}$ \\
\hline Cambodia & 0.0365 & $0.0707 *$ & $0.205^{* * *}$ & $-0.00759 * * *$ \\
\hline Cameroon & 0.0343 & $0.0736 * *$ & $0.209 * * *$ & $-0.00743^{* * *}$ \\
\hline Central African Republic & 0.0352 & $0.0723^{*}$ & $0.206 * * *$ & $-0.00755^{* * *}$ \\
\hline Chad & 0.0349 & $0.0726^{*}$ & $0.207 * * *$ & $-0.00754^{* * *}$ \\
\hline Chile & 0.0301 & $0.0721 *$ & $0.196^{* * *}$ & $-0.00734^{* * *}$ \\
\hline Colombia & 0.0321 & $0.0651^{*}$ & $0.185^{* * *}$ & $-0.00730 * * *$ \\
\hline Croatia & 0.0336 & $0.0738^{* *}$ & $0.210^{* * *}$ & $-0.00768^{* * *}$ \\
\hline Cuba & 0.0354 & $0.0721 *$ & $0.205^{* * *}$ & $-0.00748^{* * *}$ \\
\hline Democratic Republic of the Congo & 0.0322 & $0.0879 * *$ & $0.221 * * *$ & $-0.00738^{* * *}$ \\
\hline Djibouti & 0.0348 & $0.0723^{*}$ & $0.207 * * *$ & $-0.00756^{* * *}$ \\
\hline Dominican Republic & 0.044 & $0.0790 * *$ & $0.151^{* *}$ & $-0.00977 * * *$ \\
\hline Egypt & 0.0348 & $0.0727 *$ & $0.207 * * *$ & $-0.00754 * * *$ \\
\hline El Salvador & 0.037 & $0.0818^{* *}$ & $0.217^{* * *}$ & $-0.00722^{* * *}$ \\
\hline Equatorial Guinea & 0.0349 & $0.0726^{*}$ & $0.207 * * *$ & $-0.00756^{* * *}$ \\
\hline Ethiopia & 0.035 & $0.0725^{*}$ & $0.207 * * *$ & $-0.00757^{* * *}$ \\
\hline Fiji & 0.035 & $0.0726^{*}$ & $0.207 * * *$ & $-0.00756^{* * *}$ \\
\hline Gabon & 0.0358 & $0.0734^{* *}$ & $0.207^{* * *}$ & $-0.00761^{* * *}$ \\
\hline Georgia & 0.035 & $0.0725^{*}$ & $0.207 * * *$ & $-0.00756^{* * *}$ \\
\hline Greece & 0.035 & $0.0725^{*}$ & $0.207 * * *$ & $-0.00756^{* * *}$ \\
\hline Guinea & 0.0335 & $0.0745^{* *}$ & $0.207 * * *$ & $-0.00689 * * *$ \\
\hline Guinea-Bissau & 0.0418 & $0.0706^{*}$ & $0.200^{* * *}$ & $-0.00770^{* * *}$ \\
\hline Guyana & 0.035 & $0.0726^{*}$ & $0.207 * * *$ & $-0.00756^{* * *}$ \\
\hline Haiti & 0.0351 & $0.0719 *$ & $0.206^{* * *} *$ & $-0.00759 * * *$ \\
\hline Honduras & 0.031 & $0.0777 * *$ & $0.194^{* * *}$ & $-0.00746^{* * *}$ \\
\hline Indonesia & 0.0347 & $0.0722 *$ & $0.206^{* * *}$ & $-0.00751 * * *$ \\
\hline Iran & 0.035 & $0.0725^{*}$ & $0.207 * * *$ & $-0.00756^{* * *}$ \\
\hline Iraq & 0.0359 & $0.0715^{*}$ & $0.207 * * *$ & $-0.00751^{* * *}$ \\
\hline Ivory Coast & 0.035 & $0.0725^{*}$ & $0.207 * * *$ & $-0.00755^{* * *}$ \\
\hline Jamaica & 0.0344 & $0.0657^{*}$ & $0.197 * * *$ & $-0.00691 * * *$ \\
\hline Kazakhstan & 0.0364 & $0.0729 * *$ & $0.206^{* * *}$ & $-0.00770^{* * *}$ \\
\hline Kenya & 0.0348 & $0.0722^{* *}$ & $0.205^{* * *}$ & $-0.00749 * * *$ \\
\hline Kyrgyzstan & 0.0352 & $0.0723^{*}$ & $0.207 * * *$ & $-0.00757 * * *$ \\
\hline
\end{tabular}




\begin{tabular}{|c|c|c|c|c|}
\hline Lesotho & $0.0557 * *$ & 0.0704 & $0.234^{* * *}$ & $-0.00891 * * *$ \\
\hline Madagascar & 0.0351 & $0.0720^{*}$ & $0.206^{* * *}$ & $-0.00755^{* * *}$ \\
\hline Malawi & 0.0399 & $0.0669 *$ & $0.206^{* * *}$ & $-0.00872 * * *$ \\
\hline Malaysia & 0.0297 & $0.0862^{* *}$ & $0.226^{* * *}$ & $-0.00736 * * *$ \\
\hline Mauritania & 0.0346 & $0.0723 *$ & $0.206^{* * *}$ & $-0.00754 * * *$ \\
\hline Mexico & 0.0269 & $0.0885^{* *}$ & $0.237 * * *$ & $-0.00777 * * *$ \\
\hline Montenegro & 0.033 & $0.0723^{*}$ & $0.193^{* * * *}$ & $-0.00766^{* * *}$ \\
\hline Mozambique & 0.0288 & $0.0920^{* *}$ & $0.237 * * *$ & $-0.00828^{* * *}$ \\
\hline Nicaragua & 0.0329 & $0.0801 * *$ & $0.222^{* * *}$ & $-0.00763 * * *$ \\
\hline Nigeria & 0.0356 & $0.0683^{*}$ & $0.203^{* * *} *$ & $-0.00719^{* * *}$ \\
\hline Panama & 0.0347 & $0.0736^{* *}$ & $0.208^{* * *}$ & $-0.00757 * * *$ \\
\hline Papua New Guinea & 0.035 & $0.0726^{*}$ & $0.207 * * *$ & $-0.00756^{* * *}$ \\
\hline Paraguay & 0.0369 & $0.0685^{*}$ & $0.201 * * *$ & $-0.00743 * * *$ \\
\hline Peru & 0.032 & $0.0733^{* *}$ & $0.191 * * *$ & $-0.00691 * * *$ \\
\hline Philippines & 0.0395 & 0.0556 & $0.213^{* * *}$ & $-0.00810^{* * *}$ \\
\hline Republic of the Congo & 0.035 & $0.0726^{*}$ & $0.207 * * *$ & $-0.00756 * * *$ \\
\hline Republic of Vietnam & 0.0351 & $0.0724 *$ & $0.206^{* * *}$ & $-0.00753 * * *$ \\
\hline Russia & 0.0369 & $0.0703^{*}$ & $0.198^{* * *}$ & $-0.00755^{* * *}$ \\
\hline Rwanda & 0.0342 & $0.0707 *$ & $0.200^{* * *}$ & $-0.00740 * * *$ \\
\hline Senegal & 0.0383 & $0.0835^{* *}$ & $0.216^{* * *}$ & $-0.00805^{* * *}$ \\
\hline Serbia & 0.0347 & $0.0725^{* *}$ & $0.209 * * *$ & $-0.00745^{* * *}$ \\
\hline Seychelles & 0.0226 & $0.0704^{*}$ & $0.221 * * *$ & $-0.00701 * * *$ \\
\hline Sierra Leone & 0.0247 & $0.0769^{* *} *$ & $0.214^{* * *} *$ & $-0.00672 * * *$ \\
\hline Singapore & 0.0314 & $0.0732 * *$ & $0.206 * * *$ & $-0.00747 * * *$ \\
\hline South Korea & 0.0405 & $0.0717 *$ & $0.212^{* * *}$ & $-0.00849 * * *$ \\
\hline Tajikistan & 0.0349 & $0.0725^{*}$ & $0.207 * * *$ & $-0.00755^{* * *}$ \\
\hline The Gambia & 0.0295 & $0.0732 * *$ & $0.209 * * *$ & $-0.00709 * * *$ \\
\hline Togo & 0.0283 & $0.0783^{* *}$ & $0.209 * * *$ & $-0.00736 * * *$ \\
\hline Tunisia & 0.035 & $0.0727 *$ & $0.207 * * *$ & $-0.00756^{* * *}$ \\
\hline Turkey & 0.0392 & 0.0475 & $0.210^{* * *}$ & $-0.00780 * * *$ \\
\hline Uganda & 0.035 & $0.0715^{*}$ & $0.205^{* * *}$ & $-0.00752^{* * *}$ \\
\hline Yemen & 0.0352 & $0.0722 *$ & $0.207 * * *$ & $-0.00756^{* * *}$ \\
\hline Zambia & 0.0417 & $0.0728 *$ & $0.224 * * *$ & $-0.00797 * * *$ \\
\hline Zimbabwe & 0.0388 & $0.0748^{* *}$ & $0.206 * * *$ & $-0.00785 * * *$ \\
\hline
\end{tabular}

${ }^{*} p<0.10 ;{ }^{* *} p<0.05$; *** $p<0.01$. 